\title{
The petrology and genesis of the Paleoproterozoic mafic intrusion-hosted Co-Cu-Ni deposit at Hietakero, NW Finnish Lapland
}

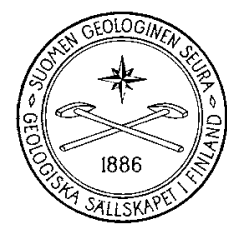

VERTAISARVIOITU KOLLEGIALT GRANSKA PEER-REVIEWED
Jukka P. Konnunaho ${ }^{I^{*}}$, Eero J. Hanski ${ }^{2}$, Tuomo T. Karinen ${ }^{\mathrm{I}}$, Yann LahaYe ${ }^{3}$, Hannu V. MaKKonen ${ }^{4}$

${ }^{1}$ Geological Survey of Finland, P.O. Box 77, FI-96101 Rovaniemi, Finland

${ }^{2}$ University of Oulu, Oulu Mining School, P.O. Box 3000, FI-90014 University of Oulu, Finland

${ }^{3}$ Geological Survey of Finland, P.O. Box 96, FI-02151 Espoo, Finland

${ }^{4}$ Boliden FinnEx Oy, Polvijärventie 22, FI-83700 Polvijärvi, Finland

\section{Abstract}

Cobalt is a highly sought-after metal due to its economic importance in many hightech applications. It is mainly obtained from sedimentary-hosted Cu-Co deposits and magmatic $\mathrm{Ni}-\mathrm{Cu}$ deposits as a by-product. We describe a recently discovered Co-enriched $\mathrm{Cu}-\mathrm{Ni}$ deposit hosted by the Hietakero mafic intrusion in north-western Finnish Lapland. The intrusion contains gabbroic to pyroxenitic cumulates and was emplaced into a supracrustal strata composed mainly of mafic volcanic rocks, sulfurbearing graphite schists and felsic volcanic interlayers. Hybrid rocks provide clear evidence for interaction of mafic magma with its country rocks. All these rocks have undergone intensive post-magmatic hydrothermal alteration by influx of $\mathrm{H}_{2} \mathrm{O}-, \mathrm{CO}_{2}$ - and $\mathrm{Cl}$-bearing saline fluids, forming strongly scapolitized ( \pm albitized) rocks and resulting in re-mobilization of sulfides and their metals.

The Hietakero deposit is associated with pyroxenitic cumulates and hybrid rocks, with the sulfides (pyrrhotite, cobaltian pentlandite, chalcopyrite and pyrite) occurring as patches, brecciated to net-textured and vein to veinlet forms. Sulfur content is $6.1 \mathrm{wt} . \%$ on average, reaching 20 wt.\% in some cases. Nickel and Cu tenors are low, but Co is elevated, resulting in very low $\mathrm{Ni} / \mathrm{Co}$ of 2.6 compared to 'classic' $\mathrm{Ni}-\mathrm{Cu}$ sulfide deposit globally. The average metal tenors are: $0.55 \mathrm{wt} . \% \mathrm{Ni}, 1.07 \mathrm{wt} \% \mathrm{Cu}$, and $0.23 \mathrm{wt} . \% \mathrm{Co}$. In-situ sulfur isotope analyses of sulfides from mineralized rocks yielded $\delta^{34} S$ values from -2.0 to $+4.5 \%$. In spite of strong post-magmatic alteration, we can conclude that the Hietakero cumulates were formed from a low-MgO and PGE-depleted basaltic magma, which developed in a staging chamber at a deeper crustal level. The magma produced compositionally different gabbroic to pyroxenitic rocks (i.e., high-Ti and lowTi groups). Model calculations indicate that the relatively high Co tenor and low $\mathrm{Ni} / \mathrm{Co}$ cannot be explained by an earlier phase of fractional crystallization or sulfide segregation. 
Instead, an external source of cobalt is needed, which is also consistent with the high $\mathrm{Zn}, \mathrm{Pb}$ and Mo contents of the mineralized rocks. Based on sulfur isotope compositions, the associated black shales were not the primary source of sulfur, but sulfur was rather derived from a so far unrecognized, potentially Co-bearing contaminant with close to mantle-like $\delta^{34} \mathrm{~S}$. Our study reveals a new Co-Cu-Ni deposit type related to the widespread Paleoproterozoic mafic magmatism in Lapland.

Keywords: Ni-Cu sulfide, cobalt, gabbro, pyroxenite, hybrid rocks, sulfur isotopes, Paleoproterozoic, Hietakero, Lapland, Finland

*Corresponding author (e-mail: jukka.konnunaho@gtk.fi)

Editorial handling: Jussi S. Heinonen (jussi.s.heinonen@helsinki.fi)

\section{Introduction}

For around 100 years, orthomagmatic Ni-Cu-PGE deposits have been an important target in base metal exploration and played an important role in the mining history in Finland (Vuorisjärvi, 1990; Haapala \& Papunen, 2015). These deposits are associated with Archean (ca. 2.8 Ga) and Paleoproterozoic (ca. $2.06 \mathrm{Ga}$ ) komatiites (Konnunaho et al., 2013; Törmänen et al., 2016), the ca. 2.44 Ga and 2.06 Ga mafic-ultramafic layered intrusions (Mutanen, 1997; Iljina et al., 2015), and the $1.88 \mathrm{Ga}$ Svecofennian orogenic mafic-ultramafic intrusions (Makkonen, 2015). Potential for the discovery of new orthomagmatic $\mathrm{Ni}$-Cu-PGE sulfide deposits in the Paleoproterozoic Central Lapland greenstone belt is highlighted by the currently operating Kevitsa mine (Santaguida et al., 2015) and the highly potential $\mathrm{Cu}-\mathrm{Ni}$-PGE deposit of Sakatti, which was discovered in 2009 (Brownscombe et al., 2015). In addition to $\mathrm{Ni}-\mathrm{Cu}$-Co sulfide deposits of orthomagmatic origin, there are also deposits in which sedimentary and hydrothermal processes have enriched commodities. The most prominent examples are the Talvivaara black shale-hosted Ni-Zn-Cu-Co deposit in central Finland (Kontinen \& Hanski, 2015) and the
$\mathrm{Cu}-\mathrm{Co}-\mathrm{Zn}-\mathrm{Ni}-\mathrm{Ag}-\mathrm{Au}$ sulfide deposits associated with the Outokumpu ophiolitic rocks in eastern Finland (Peltonen et al., 2008).

Most of the Finnish sulfide deposits associated with mafic-ultramafic rocks are enriched in $\mathrm{Ni}, \mathrm{Cu}$ and PGE, with Co as a by-product in some cases. In terms of mineral economics, Co is an important component because its price is currently about 10 times higher than that of $\mathrm{Cu}$ and about 6 times higher than that of Ni. Cobalt is a key component in lithium-ion batteries, and its price is expected to stay high due to the growing global demand for renewable energy systems (Tisserant and Pauliuk, 2016).

In this article, we describe a new Co- $(\mathrm{Cu}-\mathrm{Ni})$ enriched and PGE-poor deposit type discovered recently in NW Finnish Lapland. The mineralization is hosted by the Hietakero gabbroic intrusion emplaced into a Paleoproterozoic supracrustal belt, which has locally undergone intense scapolitization and albitization. We describe the main geological, mineralogical and geochemical features of the deposit and its host intrusion. We also use in-situ sulfur isotope analyses for assessing the potential role of country rock assimilation in the genesis of the deposit and discuss the reasons for the $\mathrm{Co}-( \pm \mathrm{Zn}-\mathrm{Pb}-\mathrm{Mo})$-rich nature of the mineralization. 


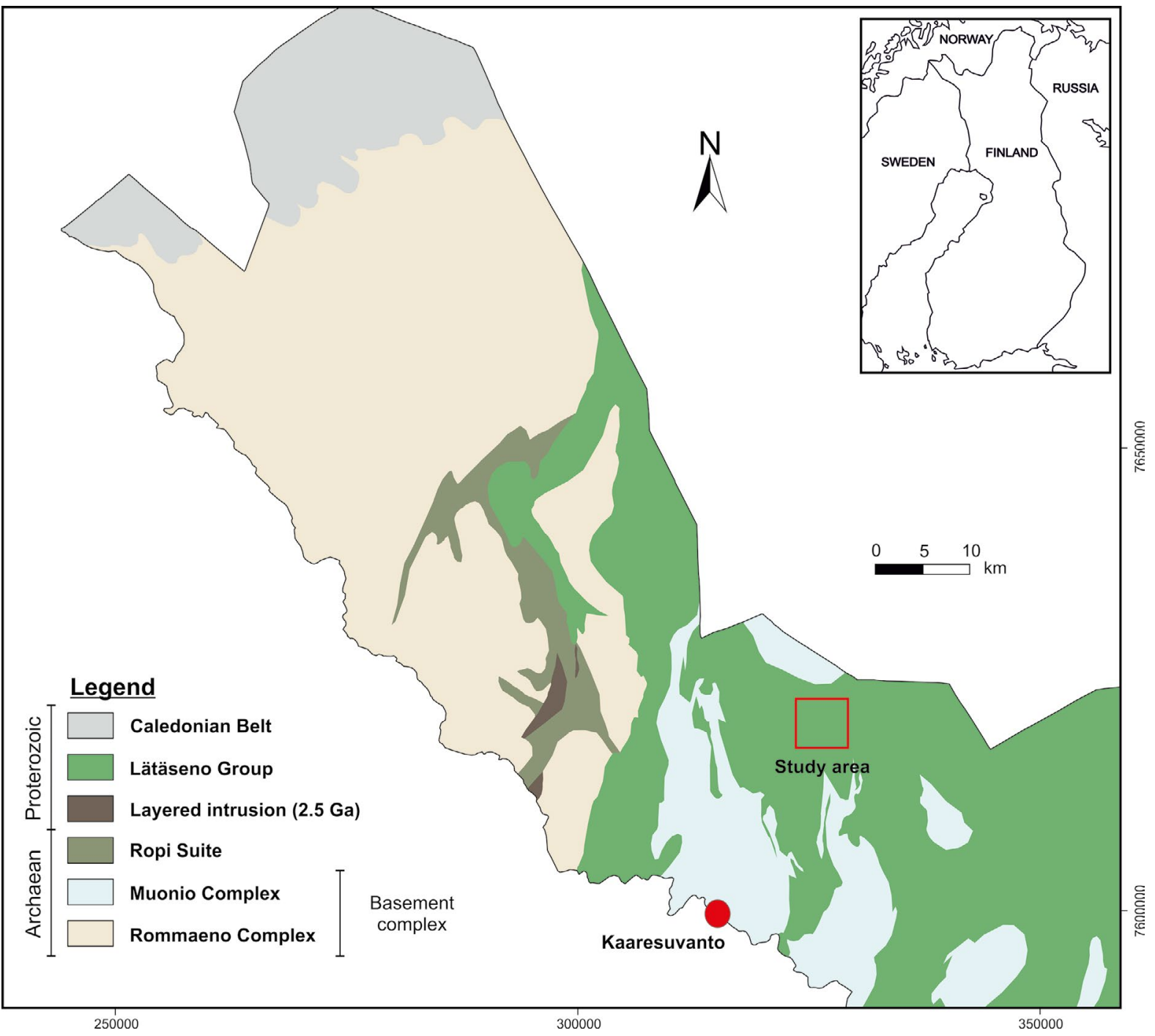

Figure 1. Simplified regional geological map (modified after Karinen et al., 2015a) and location of the study area.

\section{Regional geology}

The Hietakero mafic intrusion occurs in the northwesternmost part of Finland, around $17 \mathrm{~km}$ east from the river Lätäseno and $20 \mathrm{~km} \mathrm{NE}$ from Kaaresuvanto village. The area consists of both Archean and Paleoproterozoic bedrock. The Archean basement is divided into two parts, the Muonio Complex in the east and the Rommaeno Complex in the west (Fig. 1), with different lithological features (Karinen et al., 2015a;
DigiKP, 2017). The Muonio Complex is mainly composed of paragneisses, amphibolites, diorites to granodiorites, and minor orthogneisses (Fig. 1). The Rommaeno Complex mainly comprises leucocratic granites and granodiorites as well as metasedimentary and metavolcanic schists (amphibolites, orthogneisses, and paragneisses). The supracrustal rocks of the Rommaeno Complex belong to the Ropi Suite, forming distinct but discontinuous, EW- and NS-trending greenstone belts. (Fig. 1). U-Pb isotope data on zircon allow 
further division of the suite into lithodemes. The felsic volcanic rocks of the Sarvisoaivi lithodeme show an age of ca. $2.93 \mathrm{Ga}$ and the felsic volcanic rocks of the Tarju lithodeme are ca. $2.76 \mathrm{Ga}$ in age (Karinen et al., 2015a). These ages are similar to those determined for zircon in the plutonic rocks of the Rommaeno Complex.

According to Karinen et al. (2015a), Nironen (2017), and DigiKP (2017), the geology of the study area is dominated by Paleoproterozoic supracrustal rocks lying unconformably on the Archean basement (Figs. 1 and 2). Aeromagnetic maps indicate that these rocks continue to Sweden in the south and to Norway in the north. The volcano-sedimentary rocks are assigned to the Lätäseno Group, which is divided into, from oldest to youngest, the Palovaara, Järämä and Vikkuri Formations. The Palovaara Formation consists of metasedimentary rocks, mainly arkose quartzites and conglomerates. The Järämä Formation is composed of mafic to intermediate metavolcanic rocks including both lavas and tuffs. The former show pillow structures indicating a marine environment. In some places, these supracrustal rocks are significantly scapolitized and albitized. The lower part of the Vikkuri Formation consists of quartzcarbonate-rich metasediments and graphite-sulfide schists, which are clearly visible as conductive zones in electromagnetic maps. These rocks are overlain by felsic metatuffs and relatively magnetiterich mafic volcanic rocks characterized by strong scapolitization and albitization.

In addition to the above-mentioned supracrustal formations, there are two lithodemic units in the study area, the Hietakero and Salvastunturi lithodemes, which belong to the Olostunturi suite in the current stratigraphic division (Fig. 2). The Hietakero lithodeme consists mainly of amygdaloidal amphibolites/mafic volcanic rocks, although minor amounts of felsic to intermediate metavolcanic rocks are also found, whereas the Salvastunturi lithodeme consists of paragneisses, such as arkose and skarn quartzite and sillimanite gneiss (Fig. 2). The Paleoproterozoic rocks also include various types of felsic to intermediate plutonic rocks (i.e., Haaparanta suite), various gabbroic and serpentinite plugs, and gneissose felsic rocks (i.e., Raiseatnu gneiss).

Near the boundary between the Archean and Paleoproterozoic rocks, there are several 2.50-2.44 Ga mafic-ultramafic intrusions (e.g., Tsohkoaivi and Kelottijärvi). This magmatic event, with several orthomagmatic ore deposits, is widely recognized in the northern and eastern part of the Fennoscandian Shield (e.g., Alapieti et al., 1990; Iljina \& Hanski, 2005). At least one major younger Paleoproterozoic mafic intrusion, the Hietakero metagabbro, which hosts the orthomagmatic $\mathrm{Co}-\mathrm{Cu}-\mathrm{Ni}$ deposit and is described in this study, has intruded into the supracrustal sequence described above (i.e., Olostunturi suite and Vikkuri and Järämä Formations). Strongly albitized and magnetitebearing ca. 2.2 Ga metadiabases are also common in the supracrustal belt, mainly in the contact zone of the Archean and Paleoproterozoic rocks.

\section{Sampling and analytical methods}

The samples for this study were collected from twenty diamond drill cores obtained in 2011-2016 in a mineral potential evaluation program of the Geological Survey of Finland (GTK). The samples for petrographic studies and whole-rock analyses are homogeneous and representative splits of drill core. The collected petrological samples were generally from 10 to $30 \mathrm{~cm}$ in length. Mineralized samples for economic evaluation were taken at intervals up to $1 \mathrm{~m}$ in length with an emphasis on sulfide-bearing zones.

Semi-quantitative analyses of sulfide minerals were performed using a field emission scanning electron microscope (FESEM), and quantitative mineral analyses of silicates and sulfides were carried out with an electron probe microanalyzer (EPMA), both at the research laboratory of GTK in Espoo.

Samples were analyzed for rock compositions in Labtium Oy, an accredited geochemical laboratory in Espoo, Finland. Major and selected trace 


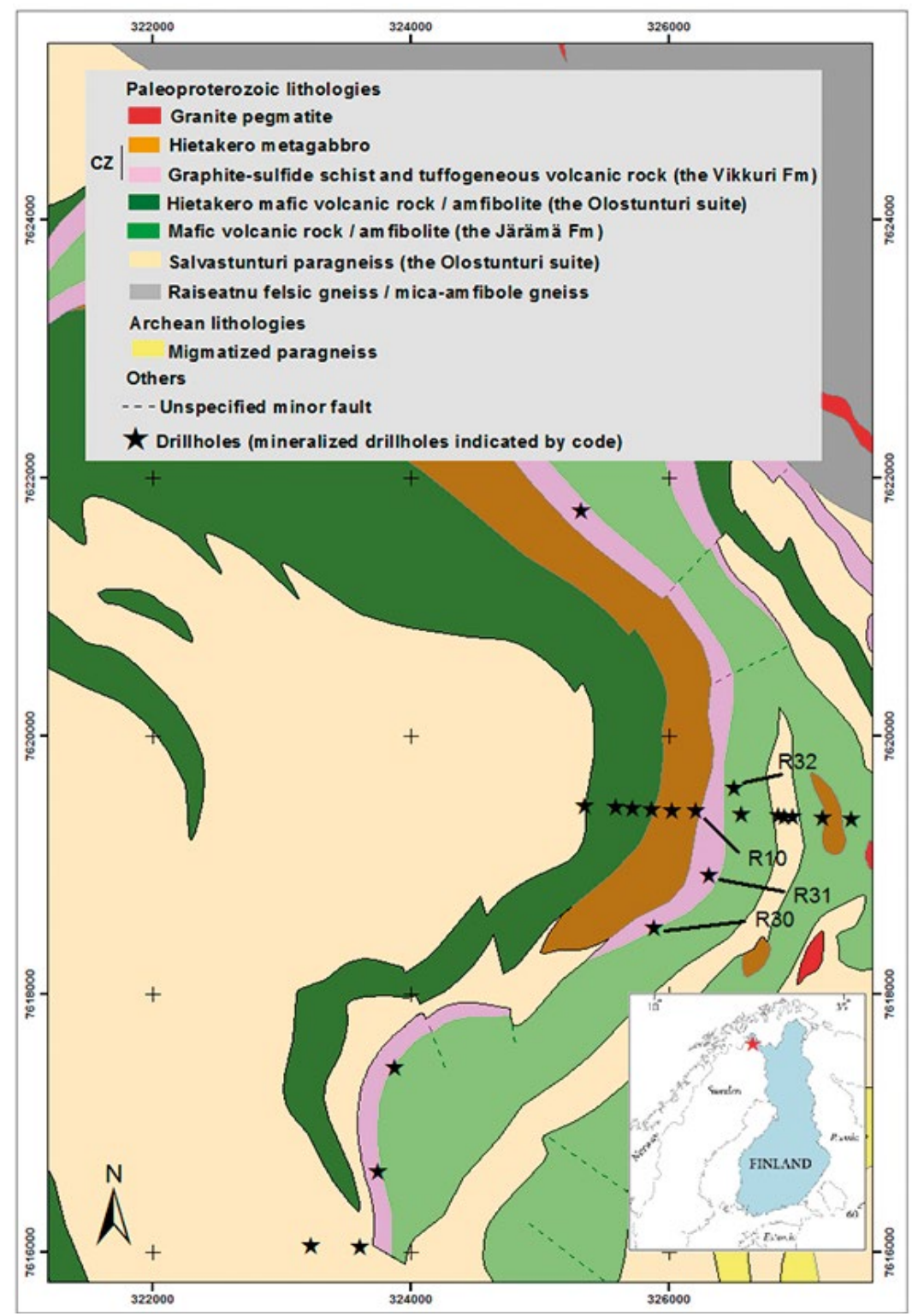

Figure 2. Geological map of the Hietakero area. Stars indicate the location of drilling sites, with the sites of mineralized drill cores being labeled with the drill hole number. $\mathrm{CZ}=$ "Critical Zone".

element concentrations were determined using X-ray fluorescence (XRF) on pressed powder pellets (method codes 175X and 176X). Rare earth elements were determined using inductivelycoupled plasma mass spectrometry (ICP-MS) after digestion with $\mathrm{HF}-\mathrm{HClO}_{4}$, supplemented with lithium metaborate-sodium perborate fusion (method code 308M; detection limit 0.01 to $20 \mathrm{ppm}$ ), or after dissolution in the mixture of $\mathrm{HF}+\mathrm{HClO}_{4}+\mathrm{HCL}+\mathrm{HNO}_{3}$ (method code 306M; detection limits from 0.1 to $0.5 \mathrm{ppm})$. Base metal concentrations (14 elements) were measured with ICP-OES (laboratory method code 510P) after partial dissolution with aqua regia (detection limits from 1 to $50 \mathrm{ppm}$ ). Palladium, platinum, and gold were determined with the $\mathrm{Pb}$ fire assay method followed by ICP-OES analysis (method codes 704P and 703P; detection limits $10 \mathrm{ppb}$ and $20 \mathrm{ppb}$ for $\mathrm{Pd}, \mathrm{Pt}$, and $\mathrm{Au}$ ).

Sulfur isotope analyses of sulfides were performed with a $\mathrm{Nu}$ Plasma HR multicollector inductively coupled plasma mass spectrometer 
equipped with a Photon Machine Analyte G2 laser microprobe at the Geological Survey of Finland in Espoo. The samples were ablated in He gas (gas flows $=0.4$ and $0.1 \mathrm{l} / \mathrm{min}$ ) within a HelEx ablation cell (Müller et al., 2009). Sulfur isotopes were analyzed at medium resolution and all measurements were made in static mode. Single-spot pyrite samples were ablated at a spatial resolution of 40 micrometers, using a fluence of $3.5 \mathrm{~J} / \mathrm{cm}^{2}$ at 2 to $4 \mathrm{~Hz}$. The total $S$ signal obtained for pyrite was $0.5-1.5 \mathrm{~V}$. Under these conditions, after a $20 \mathrm{~s}$ baseline measurement, 50-60 s of ablation is needed to obtain an internal precision of less than $\pm 0.000005(1 \sigma)$ for ${ }^{34} \mathrm{~S} /{ }^{32} \mathrm{~S}$. Two pyrite standards were utilized for external standard bracketing (PPP-1; Gilbert et al., 2014) and quality control (in house standard Py2). The isotope composition of the in-house pyrite standard Py2 has previously been determined with gas mass spectrometry. Compared with the $\delta^{34}$ S CDT (\%o) reference value of $-0.4 \pm 0.5 \%$ o $(1 \sigma)$, we obtained an identical average value of $-0.4 \pm 0.2 \%$ o $(2 \sigma, n=4)$. The inhouse pyrrhotite standard Polo was also used for quality control. For this, we obtained an average $\delta^{34} S$ value of $6.1 \pm 0.3 \%$ o $(2 \sigma, n=2)$, while the reference value is $5.6 \pm 0.6 \%$ o $(1 \sigma)$. Chalcopyrite samples were ablated using the same laser ablation parameters. Two in-house chalcopyrite standards were employed for external standard bracketing and quality control. These standards were earlier analyzed by gas mass spectrometry, yielding a $\delta^{34}$ S CDT (\%o) value of $-0.7 \pm 0.5 \%$. Our insitu analyses resulted in an average $\delta^{34} S$ value of $-1.1 \pm 1.2 \%$ o $(2 \sigma, \mathrm{n}=5)$.

\section{Hietakero intrusion and its country rocks}

The Hietakero mafic to ultramafic intrusion forms an arcuate body with a surficial length of ca. $9 \mathrm{~km}$ and a width of ca. $1 \mathrm{~km}$. So far, the surrounding area is poorly investigated and the volume of the Hietakero mafic intrusive body may be much larger than currently known. The intrusion was emplaced into Paleoproterozoic supracrustal strata of the Hietakero lithodeme and Vikkuri and Järämä Formations. The intrusion displays a weak magnetic anomaly, which, on its eastern side, parallels the distinct magnetic anomalies of the Järämä Formation rocks and the highly conductive sulfide-bearing schists of the Vikkuri Formation; the latter has been precisely located by electromagnetic maps and is called "the critical zone" (CZ) (Fig. 2). At its western contact, the intrusion roughly parallels the weak but distinct magnetic anomalies of the Hietakero lithodeme rocks. Based on the 3D modelling of the Hietakero area, the arcuate structure has been explained by roughly orthogonal N-S- and E-W-directed folding stages (Karinen et al., 2015b). The ages of the Hietakero mafic intrusion and its country rocks are not precisely known (i.e., no isotopic age data available), but its cross-cutting relationship and the correlation of the associated supracrustal rocks with other Paleoproterozoic greenstone belts in northern Lapland (Finland and Sweden) suggest that they are Paleoproterozoic in age (e.g., Bergman et al., 2001; Karinen et al., 2015a; DigiKp, 2017).

The Hietakero mafic intrusion consists of a series of metamorphosed and metasomatized gabbroic to pyroxenitic cumulates and hybrid rocks, formed during the interaction of the magma with supracrustal country rocks. The country rocks are composed mostly of graphite-sulfide schists and tuffogeneous felsic to intermediate volcanic rocks. The study area has metamorphosed under middle amphibolite facies conditions. In addition, the Hietakero area has undergone post-magmatic hydrothermal alteration, such as scapolitization.

\subsection{Gabbroic cumulates}

Gabbroic rocks represent the most voluminous rock type in the intrusion, whereas olivine-rich cumulates are absent. The gabbroic cumulates form a texturally heterogeneous group of subophitic to granoblastic rocks, in which the amphibolitic varieties commonly display a well-oriented texture. They are divided into the following main types: 
gabbro, scapolite gabbro, amphibolitic scapolite gabbro, amphibolitic gabbro, and subophitic gabbro. Gabbroic cumulates are composed of fine- to medium-grained amphibole (actinolite/ hornblende), clinopyroxene (diopside), Ca-rich scapolite, and plagioclase. Magnetite and ilmenite are also common. A varying amount of scapolite is a characteristic feature of most of the gabbroic rocks. The scapolite-rich varieties are called scapolite gabbros, which are the most dominant among the gabbroic cumulates. Some of these cumulates are also albitized, as manifested by a light reddish color in the rocks. Accessory silicate minerals include biotite, chlorite (chamosite), carbonate, talc, epidote/zoisite, saussurite, titanite, and apatite, with most of them being alteration products of the main silicate minerals. Sulfides are also found outside the mineralization as a sporadic dissemination of pyrrhotite, chalcopyrite, pentlandite, and pyrite. Because of their higher contents of magnetite, gabbros, amphibolitic gabbros, and subophitic gabbros are commonly more magnetic than scapolite-bearing metagabbros and pyroxenites, from which magnetite was dissolved during metasomatism (cf. Engvik et al., 2011).

Plagioclase compositions were determined from three gabbroic samples, in which plagioclase is oligoclase-albite $\left(\mathrm{Ab}_{>78}\right)$. Clinopyroxene in the gabbroic cumulates is diopsidic, ranging in composition from $\mathrm{Wo}_{47} \mathrm{En}_{37} \mathrm{Fs}_{16}$ to $\mathrm{Wo}_{48} \mathrm{En}_{41} \mathrm{Fs}_{11}$, as determined from two samples.

\subsection{Pyroxenitic cumulates}

Pyroxenitic cumulates are less voluminous compared to the gabbroic cumulates. On the basis of drill cores, the pyroxenitic cumulates occur among gabbroic cumulates and their position in the igneous stratigraphy is still uncertain. In the transition zone between pyroxenites and gabbros, there is often a hybrid zone containing both rock types. The Hietakero mineralization is related to pyroxenitic cumulates and spatially associated hybrid rocks. The ultramafic rocks consist of clinopyroxene (diopside), amphibole, and minor amounts of plagioclase and scapolite. These rocks can be divided into diopside-rich and amphibole-rich pyroxenites, both varying into plagiopyroxenites. Diopside-rich pyroxenites are common in the mineralized sequence. They are typically scapolite-poor, whereas dark green, homogeneous and fine-grained amphibole( \pm scapolite)-rich pyroxenites are found outside the well-mineralized zone as dikes, layers, or patches. Biotite, talc, carbonate, serpentine, chlorite, and epidote/zoisite are common accessory silicate minerals. The pyroxenitic cumulates are commonly sulfide mineralized (see below).

The clinopyroxene in the studied five pyroxenitic samples is diopsidic, but compared to the diopside in gabbroic cumulates, it is compositionally more variable, ranging from $\mathrm{Wo}_{47} \mathrm{En}_{39} \mathrm{Fs}_{14}$ to $\mathrm{Wo}_{49} \mathrm{En}_{50} \mathrm{Fs}_{1}$. The scapolite group minerals that were analyzed from three pyroxenite samples contain 46-81 mol.\% marialite and are defined as calcian marialites in the classification of Teertstra \& Sherriff(1997).

\subsection{Hybrid rocks}

The hybrid rocks are texturally very heterogeneous, and as they are found in the mineralized zone and are commonly also mineralized (Fig. 3), their location in the geological map is referred to as "the critical zone" (CZ) (Fig. 2). The hybrid rocks are divided into three main groups: Hybrid rock 1 consists of mafic, commonly pyroxenitic material and minor felsic volcanic enclaves of variable size, bybrid rock 2 is a mixture of felsic country rock and minor pyroxenitic material, and hybrid rock 3 is a mixture of gabbroic and pyroxenitic cumulates. All hybrid rocks are enriched in sulfide minerals (see below).

\subsection{Country rocks}

Graphite-sulfide schists along the contact zone of the Hietakero intrusion are black, fine-grained, schistose, and partly brecciated. They commonly contain variable amounts of sulfides, which are 

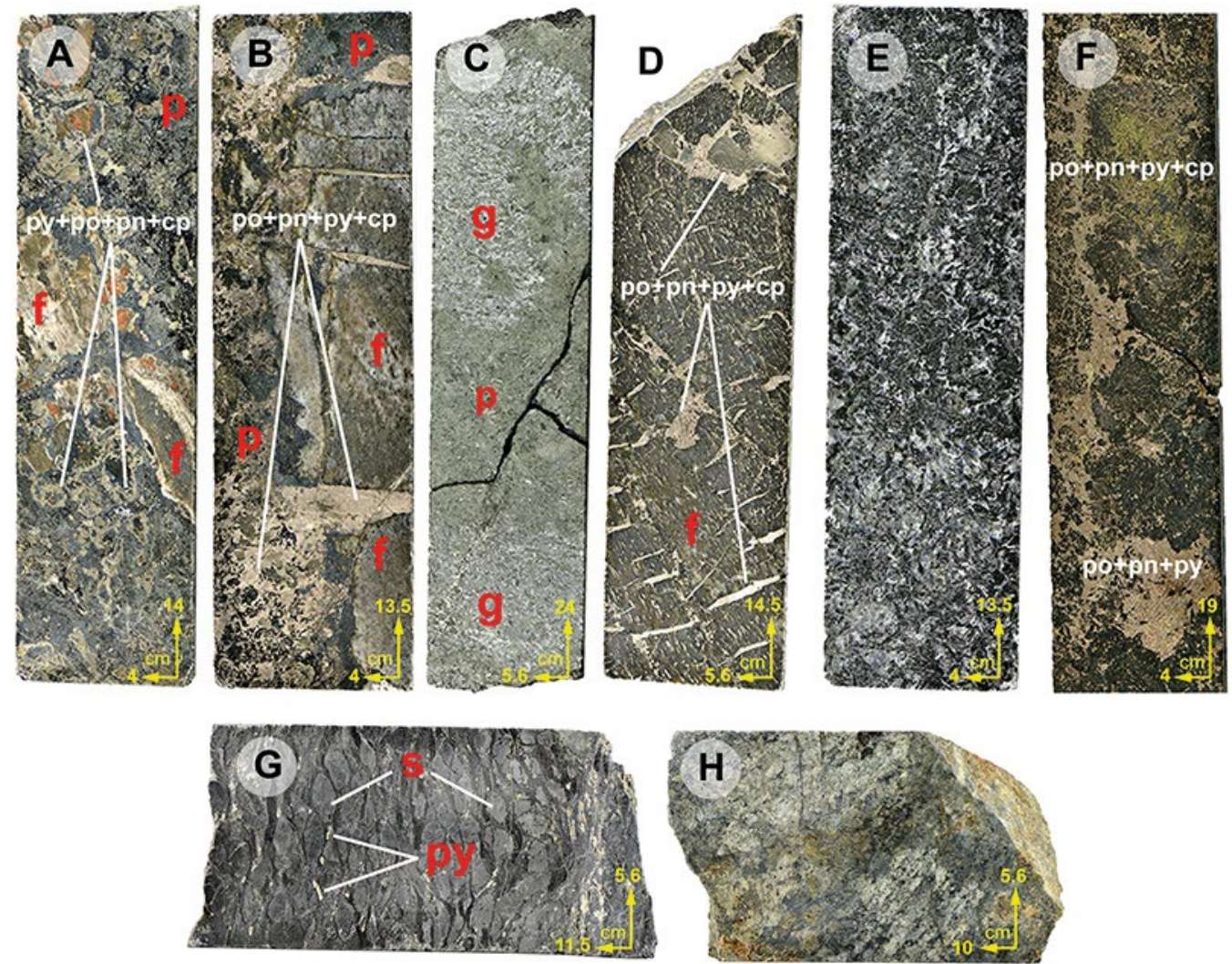

Figure 3. Representative drill core samples from the Hietakero deposit: A) Mineralized $(p y+p o+p n+c p)$ hybrid rock 1 (drill core R10), B) mineralized ( $p o+p n+p y+c p$ ) hybrid rock 2 (drill core R10), C) unmineralized hybrid rock 3 (drill core R31), D) mineralized ( $p o+p n+p y+c p$ ) felsic volcanic rock / hornfels (drill core R10), E) unmineralized magnetite-bearing gabbroic cumulate (drill core R9), F) typical mineralized (po-pn-py-cp) (veinlets+patches+dissemianated sulfides) hybrid rock (drill core R10), G) sulfide-bearing graphite breccia (drill core R29), and H) mineralized (py+cp+po+pn) pyroxenite (drill core R31). Abbreviations: $p y=$ pyrite, $p o=$ pyrrhotite, $c p=$ chalcophyrite, Co-pn $=$ Co-pentlandite, $f=$ felsic volcanic rock $/$ hornfels, $p=$ pyroxenitic rock, $g=$ gabbroic rock, $s=$ scapolite-( \pm diopside $)$.

mainly pyrite accompanied with minor pyrrhotite and chalcopyrite. Graphite is present mostly as a fine-grained dissemination but in places, it occurs as coarse flakes. Common with other rocks in the Hietakero area, graphite-sulfide schists are strongly metasomatized (i.e., scapolitized). Macroscopically, these altered rocks are called graphite breccias. They consist of ovoid scapolite porphyroblasts up to $5 \times 10 \mathrm{~mm}$ in size, surrounded by scapolite-biotitediopside-sulfide-graphite material. In places, also diopside displays a similar porphyroblastic texture. These porphyroblasts are rimmed by a zone of fine-grained graphite dissemination. The most intensively altered graphite schists are light gray and graphite is almost vanished, but scapolite and diopside porphyroblasts are still covered by dense graphite dissemination (Fig. 3).

The supracrustal sequence also contains tuffogenic felsic to intermediate volcanic rock interlayers. These rocks are commonly light gray, fine-grained, oriented and clearly laminar. In the mineralized zone and xenoliths in the hybrid rocks, they are massive, homogeneous, fine-grained and light gray and enriched in sulfides (pyrrhotite, pyrite, chalcopyrite, and cobaltian pentlandite). Pyrrhotite-( \pm pyrite) occurs commonly as injected veinlets and breccias and chalcopyrite as finegrained dissemination and thin veinlets. The felsic xenoliths and felsic volcanic rocks were probably altered and partly recrystallized (i.e., hornfels) 
by the emplacement of the mafic intrusion and mineralization process, especially in the mineralized zone (Fig. 3). The felsic to intermediate volcanic rocks consist mainly of quartz, plagioclase, and diopside, with sericite, biotite, amphibole, rutile, apatite, carbonate, and monazite occurring being the main accessory minerals. Scapolite is rare in felsic volcanic rocks, but it can be found in mafic, biotite-amphibole-chlorite-rich interlayers as rounded porphyroblasts. Typically, all felsic to intermediate volcanic rocks contain variable amounts of diopside, which is commonly associated with injected sulfides in the mineralized rocks. Occasionally, diopside also occurs as veinlets and single grains in unmineralized felsic to intermediate volcanic rocks.

\section{Hietakero Co-Cu-Ni mineralization}

The Hietakero $\mathrm{Co}-\mathrm{Cu}-\mathrm{Ni}$ mineralization, which is associated with gabbroic to pyroxenitic rocks, hybrid rocks, and felsic volcanic rocks, was discovered during a drilling campaign of the GTK mineral potential mapping project in 2012. The tenth drill hole (V4222012R10) intersected two mineralized horizons at depths of 173.8-177.8 m and $194.80-208.80 \mathrm{~m}$, with average metal contents of 0.11 wt. $\%$ Co, 0.35 wt. $\% \mathrm{Cu}$, and 0.20 wt. $\%$ $\mathrm{Ni}$ in the former and 0.1 wt.\% Co, 0.31 wt. $\% \mathrm{Cu}$, and 0.23 wt.\% $\mathrm{Ni}$ in the latter (Fig. 4). The most important metal-bearing sulfides are Co-bearing pentlandite (ca. 10 to 14 wt.\% of Co), pyrite (ca. 0 to 4 wt.\% Co) and chalcopyrite. Because of the scattered drill hole locations, no mineral resource estimate is currently available.

Drilling data indicate that the mineralized zone is around $600 \mathrm{~m}$ long, but its continuation is still open to the north and south and the dip direction as well. This electromagnetically positive and continuous "critical zone" is several kilometers long and so far, it has been tested by drilling only in a few places. The thickness of the mineralization is variable, ranging from meters up to tens of meters, and poorly confirmed due to the limited amount of drilling. Based on the interpretation of a SkyTEM electromagnetic survey, the depth of electromagnetic response is at least ca. $500 \mathrm{~m}$.

The drilled intersections of the mineralization have revealed two main ore mineral assemblages: 1) pyrite with minor pyrrhotite-(+Co-bearing pentlandite) and chalcopyrite and 2) pyrrhotite(+Co-bearing pentlandite)-chalcopyrite with pyrite. Of the base metals, the former type is enriched mainly in $\mathrm{Cu}$ and the second type in $\mathrm{Co}$, $\mathrm{Cu}$ and $\mathrm{Ni}$. The main sulfide minerals are pyrrhotite, pyrite, cobaltian pentlandite, and chalcopyrite. Pyrrhotite and pyrite occur commonly as massive veins, veinlets, patches, and as brecciated to nettextured forms. Sulfides, commonly pyrite, are often surrounded by silicates, such as diopside grains, forming lacy textures. Disseminated sulfides also occur, but they are rare compared to other sulfide types. Chalcopyrite occurs in mineralized rocks as a sporadic fine dissemination and thin veinlets together with other sulfides, but it is typically higher in abundance felsic volcanic rocks in the mineralized zone. Cobalt-bearing pentlandite is associated with pyrrhotite ( $\leq 0.5$ wt. $\%$ of $\mathrm{Ni}$ and no $\mathrm{Co}$ ) as exsolutions. Other accessory sulfides are melonite $\left(\mathrm{NiTe}_{2}\right)$, molybdenite $\left(\mathrm{MoS}_{2}\right)$, and solid solutions of the linnaeite-polydymite series $\left(\mathrm{Co}^{+2} \mathrm{Co}_{2}^{+3} \mathrm{~S}_{4}-\mathrm{Ni}^{+2} \mathrm{Ni}_{2}^{+3} \mathrm{~S}_{4}\right)$. Pyrite is low in Co (commonly $<1$ wt.\%). The ore mineralogy is still poorly investigated and the elevated $\mathrm{Pb}$ and $\mathrm{Zn}$ contents indicate that possibly galena and sphalerite also occur in the Hietakero mineralized rocks.

The common oxide minerals, magnetite and ilmenite, are typically found as a fine dissemination and sometimes as larger grains. Both minerals occur as separate grains and ilmenite also as lamellae in magnetite grains. The high variation in magnetite content is clearly reflected in the measured susceptibility values and that in the ilmenite content in bulk-rock $\mathrm{TiO}_{2}$ abundances. Despite the wide metasomatic alteration in the Hietakero area, oxidative replacement of the original sulfides by secondary magnetite, such as what has happened in the Vaara Ni-Cu-PGE deposit (Konnunaho et al., 2013), for example, is not observed. 


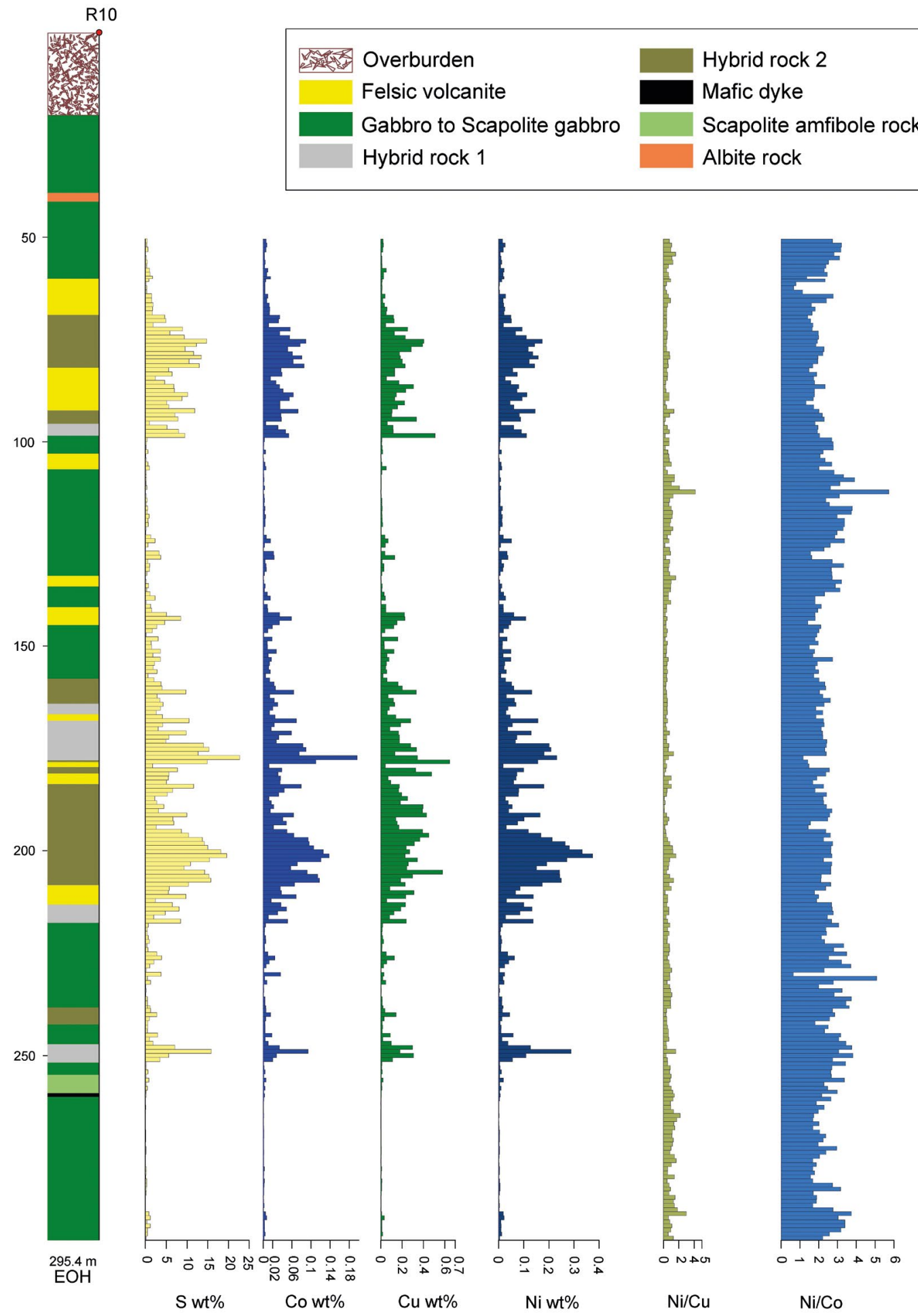

Figure 4. Variations in concentration of $\mathrm{S}, \mathrm{Ni}, \mathrm{Cu}$ and $\mathrm{Co}$ and metal ratios across mineralized drill core (R10). Drillhole location is shown in Fig. 2. 


\section{Major and trace element geochemistry}

\subsection{General features}

The compositions of mafic to ultramafic cumulates are mainly controlled by the modal variation of metamorphic silicate minerals, such as diopside, amphibole, scapolite, and albite. Other compositionally important silicate minerals are plagioclase and quartz. The modal variations of ilmenite and magnetite also control some of the element concentrations in the cumulates. Average compositions and some representative whole-rock analyses of the gabbroic and pyroxenitic rocks from Hietakero are listed in Table 1.

Figures $5 \mathrm{a}-\mathrm{d}$ show major element variations as a function of $\mathrm{MgO}$ in the Hietakero gabbroic and pyroxenitic cumulates. The gabbroic cumulates are characterized by $\mathrm{MgO}$ contents of -5 to 10 wt.\%, being rather homogeneous and lacking strongly fractionated derivatives. The $\mathrm{MgO}$ content of the pyroxenites is also limited, ranging from -13 to 15 wt. $\%$. The $\mathrm{TiO}_{2}$ content in the gabbroic cumulates varies widely between $\sim 0.4$ and $2.4 \mathrm{wt} . \%$ and in the pyroxenitic rocks between -0.6 and 1.4 wt.\%. Based on $\mathrm{TiO}_{2}$ content, the rocks can be divided into high- $\mathrm{TiO}_{2}$ (ave. -1.7 wt.\%) and low- $\mathrm{TiO}_{2}(-0.95$ wt.\%) types, which both form separate trends in Fig. 5a. In the gabbroic cumulates, the $\mathrm{Al}_{2} \mathrm{O}_{3}$ content ranges commonly from -13 to $16 \mathrm{wt} . \%$ and in the pyroxenites, it is $-10-13 \mathrm{wt} \%$ (Fig. 5b). $\mathrm{Al}_{2} \mathrm{O}_{3} / \mathrm{TiO}_{2}$ (not shown) is significantly higher in low $-\mathrm{TiO}_{2}$ rocks $(-15.2)$ compared to the high- $\mathrm{TiO}_{2}$ rocks $(-8.6)$. The $\mathrm{CaO}$ content of the gabbroic cumulates varies mainly between -7 to $12 \mathrm{wt} . \%$ and in the pyroxenites from -10 to 12 wt. $\%$, being highest in diopside-( \pm amphibole)rich rocks (Fig. 5c).

Variation in the $\mathrm{Na}_{2} \mathrm{O}$ and $\mathrm{Cl}$ contents is a reflection of the degree of alteration of the gabbroic cumulates. The $\mathrm{Na}_{2} \mathrm{O}$ content varies between -5 and 8 wt.\% in the gabbroic cumulates, being -9.5 wt. $\%$ in the most scapolite-rich gabbros and $-10.5 \mathrm{wt} . \%$ in albite-rich gabbros, while in the pyroxenites, it falls between -2.5 and $4.5 \mathrm{wt} . \%$. The chlorine contents vary between -0.1 and $1.8 \mathrm{wt} . \%$ in gabbroic cumulates, being directly related to the scapolite content of the rocks, and between -0.2 and 0.4 wt. $\%$ in scapolite-poor pyroxenites (Figs. 5e-f).

Chromium content is generally low $(<0.05$ wt.\%) both in the gabbroic and pyroxenitic rocks. It has a positive correlation with $\mathrm{MgO}$ in the gabbroic rocks, but not the pyroxenitic rocks. $\mathrm{P}_{2} \mathrm{O}_{5}$ and $\mathrm{Zr}$ show a relatively wide scatter $(-0.03$ to 0.25 wt. $\%$ and -20 to $160 \mathrm{ppm})$ and a positive correlation with $\mathrm{TiO}_{2}$ (not shown). High-Ti gabbroic rocks have higher $\mathrm{P}_{2} \mathrm{O}_{5}$ and $\mathrm{Zr}$ concentrations compared to low-Ti gabbroic rocks at given $\mathrm{MgO}$ contents.

Chondrite-normalized REE patterns of the main rock types from the Hietakero area are presented in Figs. 6a-f. For the gabbroic rocks, REE data are shown separately for the high-Ti and lowTi groups (Fig. 6b). The high-Ti rocks (gabbroic to pyroxenitic cumulates) show deeply sloping patterns with $(\mathrm{La} / \mathrm{Sm})_{\mathrm{CN}}$ averaging -1.8 and $\left.(\mathrm{Gd} / \mathrm{Yb})_{\mathrm{CN}}-1.7\right)$ (Fig. 6a). The Low-Ti gabbroic rocks commonly display flat HREE and flat or slightly LREE-enriched patterns with average (La/ $\mathrm{Sm})_{\mathrm{CN}}$ of -1.3 and $\left.\mathrm{Gd} / \mathrm{Yb}\right)_{\mathrm{CN}}$ of -1.2 ) (Fig. 6b). The high-Ti rocks are also enriched in other incompatible trace elements, such as $\mathrm{Zr}$ (70-160 ppm) and $\mathrm{Nb}(4-10 \mathrm{ppm})$ compared to the $\mathrm{Ti}$ depleted rocks (30-70 ppm $\mathrm{Zr}$ and 0.5-4 ppm Nb). Some of the Eu anomalies in the gabbroic rocks were caused by secondary loss of Ca during albitization. Felsic volcanic rocks and graphite schists are strongly enriched in LREE and show variable negative Eu anomalies (Fig. 6d). Mafic volcanic rocks and amphibolites differ from the high-Ti gabbroic and pyroxenitic rocks in having, in most cases, flat or only slightly fractionated REE patterns (Figs. 6e and f). These patterns are comparable to those of some low-Ti gabbroic rocks (Figs. 6b). 
Table 1. Representative whole-rock analyses of the Hietakero rocks

\begin{tabular}{|c|c|c|c|c|c|}
\hline Sample & S16008332 & L12090510 & L12090518 & 14 & L12090535 \\
\hline Rock type & Strongly scapolitized gabbro & Ti-enriched scapolite gabbro & Ti-depleted scapolite gabbro & Pyroxenite & Felsic volcanic \\
\hline Core/depth & R29/153.32 & $\mathrm{R} 6 / 100.75$ & $\mathrm{R} 7 / 100.75$ & $\mathrm{R} 31 / 152.83$ & $\mathrm{R} 10 / 212.40$ \\
\hline SiO2 (wt.\%) & 50 & 47.2 & 48.1 & 40.77 & 72 \\
\hline $\mathrm{TiO} 2$ & 2.3 & 1.64 & 0.52 & 1.24 & 0.68 \\
\hline $\mathrm{Al} 203$ & 10 & 13.8 & 13.9 & 10.46 & 15.8 \\
\hline Fe203tot & 10 & 14.3 & 13.7 & 14.4 & 1.22 \\
\hline $\mathrm{MnO}$ & 0.038 & 0.076 & 0.174 & 0.042 & b.d. \\
\hline MgO & 5.3 & 7.54 & 7.54 & 13.3 & 0.08 \\
\hline $\mathrm{CaO}$ & 8.3 & 7.43 & 10.28 & 9.56 & 0.52 \\
\hline $\mathrm{Na} 2 \mathrm{O}$ & 7.20 & 5.72 & 4.35 & 2.47 & 9.33 \\
\hline K2O & 0.45 & 0.98 & 0.57 & 0.69 & 0.083 \\
\hline P205 & 0.24 & 0.14 & 0.044 & 0.011 & 0.042 \\
\hline $\mathrm{Cu}$ & 0.003 & 0.03 & b.d. & 0.013 & 0.007 \\
\hline $\mathrm{Cr}$ & 0.012 & 0.03 & 0.022 & 0.017 & 0.014 \\
\hline $\mathrm{S}$ & 0.002 & 0.399 & 0.037 & 0.43 & 0.222 \\
\hline $\mathrm{Sr}$ & 0.01 & 0.01 & 0.007 & 0.001 & 0.004 \\
\hline $\mathrm{Ba}$ & b.d. & 0.01 & b.d. & b.d. & b.d. \\
\hline $\mathrm{Zn}$ & 0.002 & b.d. & 0.005 & b.d. & b.d. \\
\hline As & 0.00 & b.d. & b.d. & b.d. & b.d. \\
\hline $\mathrm{Cl}$ & 1.77 & 0.942 & 0.863 & 0.21 & 0.013 \\
\hline Th (ppm) & 5.89 & b.d. & 0.53 & b.d. & 15.7 \\
\hline La & 18.42 & 15 & 5.99 & 8.1 & 59.1 \\
\hline $\mathrm{Ce}$ & 50.57 & 21.4 & 9.2 & 29.3 & 89.9 \\
\hline $\mathrm{Sm}$ & 5.84 & 3.36 & 1.25 & 6.2 & 4.74 \\
\hline $\mathrm{Eu}$ & 1.43 & 0.96 & 0.6 & 1.5 & 0.68 \\
\hline $\mathrm{Gd}$ & 5.81 & 4.86 & 2.44 & 6.8 & 4.6 \\
\hline $\mathrm{Tb}$ & 0.94 & 0.83 & 0.47 & 1.1 & 0.66 \\
\hline Dy & 5.77 & 5.2 & 3.49 & 7.3 & 4.11 \\
\hline $\mathrm{Ho}$ & 1.17 & 1.08 & 0.82 & 1.6 & 0.87 \\
\hline $\mathrm{Er}$ & 3.31 & 3.08 & 2.6 & 4.8 & 2.7 \\
\hline $\mathrm{Tm}$ & 0.46 & 0.44 & 0.39 & 0.7 & 0.42 \\
\hline $\mathrm{Yb}$ & 28.55 & 2.67 & 2.66 & 4.5 & 2.78 \\
\hline $\mathrm{Lu}$ & 0.42 & 0.41 & 0.41 & 0.7 & 0.42 \\
\hline $\mathrm{Zr}$ & 114.45 & 93.9 & 58.8 & 80.3 & 144 \\
\hline$U$ & 2.51 & 1.77 & 0.38 & 0.4 & 18.9 \\
\hline Y & 2.9 & 24.7 & 19.9 & 36.4 & 21.4 \\
\hline V & 375.52 & 278 & 276 & 345 & 156 \\
\hline $\mathrm{Sc}$ & 37.07 & 36.1 & 49.7 & 34.4 & 12.4 \\
\hline $\mathrm{Nb}$ & 15.78 & 4.5 & 0.86 & 6 & 10.5 \\
\hline $\mathrm{Rb}$ & 7.20 & 34.7 & 6.26 & 19.9 & 0.51 \\
\hline $\mathrm{Hf}$ & 3.18 & 2.59 & 1.58 & 2.8 & 3.86 \\
\hline Co & 27.59 & 49.6 & 47.7 & 52 & 18.1 \\
\hline
\end{tabular}

* Note: Loss on ignition was not determined. b.d. = below detection limit 

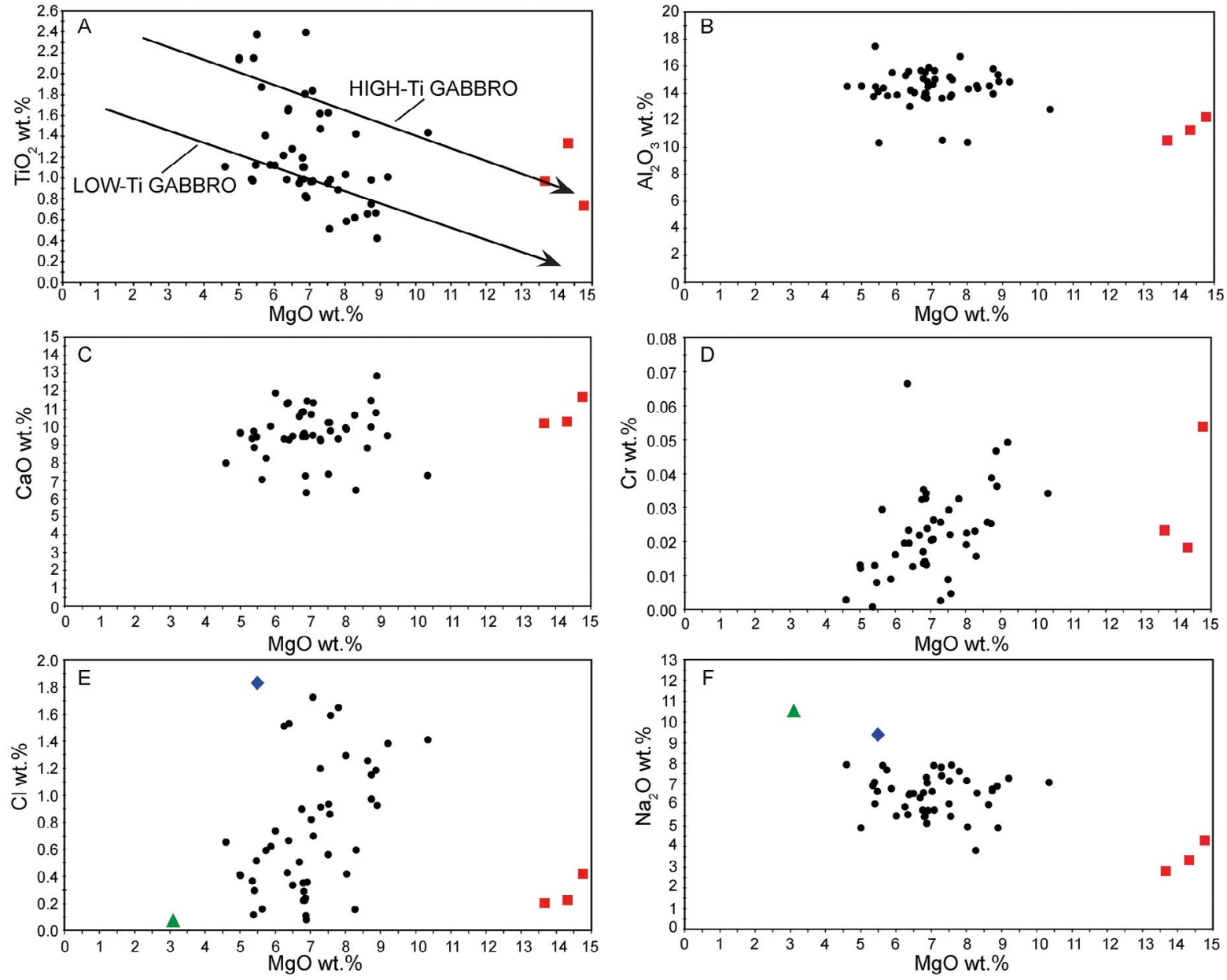

- Gabbro - Scapolite gabbro

Strongly albitized rock (figs. d and e)

- Pyroxenitic rock

Strongly scapolitized rock (figs. $d$ and e)

Figure 5. Whole-rock compositions of unmineralized Hietakero rocks. a) MgO (wt.\%) vs. TiO2 (wt.\%), b) MgO (wt.\%) vs. Al2O3 (wt.\%), c) MgO (wt.\%) vs. CaO (wt.\%), d) MgO (wt.\%) vs. Cr (wt.\%), e) MgO (wt.\%) vs. Cl (wt.\%), and f) MgO (wt.\%) vs. Na2O (wt.\%). Strongly albitized and scapolitized rocks are marked with separate symbols.

\subsection{Chalcophile elements}

Selected chalcophile element analyses from the Hietakero mineralization are presented in Table 2. In the mineralized drill core intervals $(S>1.0 \mathrm{wt} . \%)$ analyzed most often as 1.0 -m-long intervals, the sulfur content is $6.1 \mathrm{wt} . \%$ on average, reaching 20 wt.\% in some cases (Fig. 4). Chalcophile element concentrations, especially those of $\mathrm{Ni}$ and $\mathrm{Co}$, are dependent on the amount of sulfides and their types, i.e., the pyrrhotite-dominant mineralization type is clearly enriched in $\mathrm{Co}$ and $\mathrm{Ni}$ compared to the pyrite-dominant mineralization. In contrast, the $\mathrm{Cu}$ content has a less strict relationship with the sulfur content or rock type.

Nickel, cobalt, and sulfur show, in general, very good positive correlations, with the trends projecting to the origin of the diagrams, but the plot of $\mathrm{Cu}$ against sulfur is more scattered, indicating post-magmatic mobilization of $\mathrm{Cu}$ (Fig.7c). 

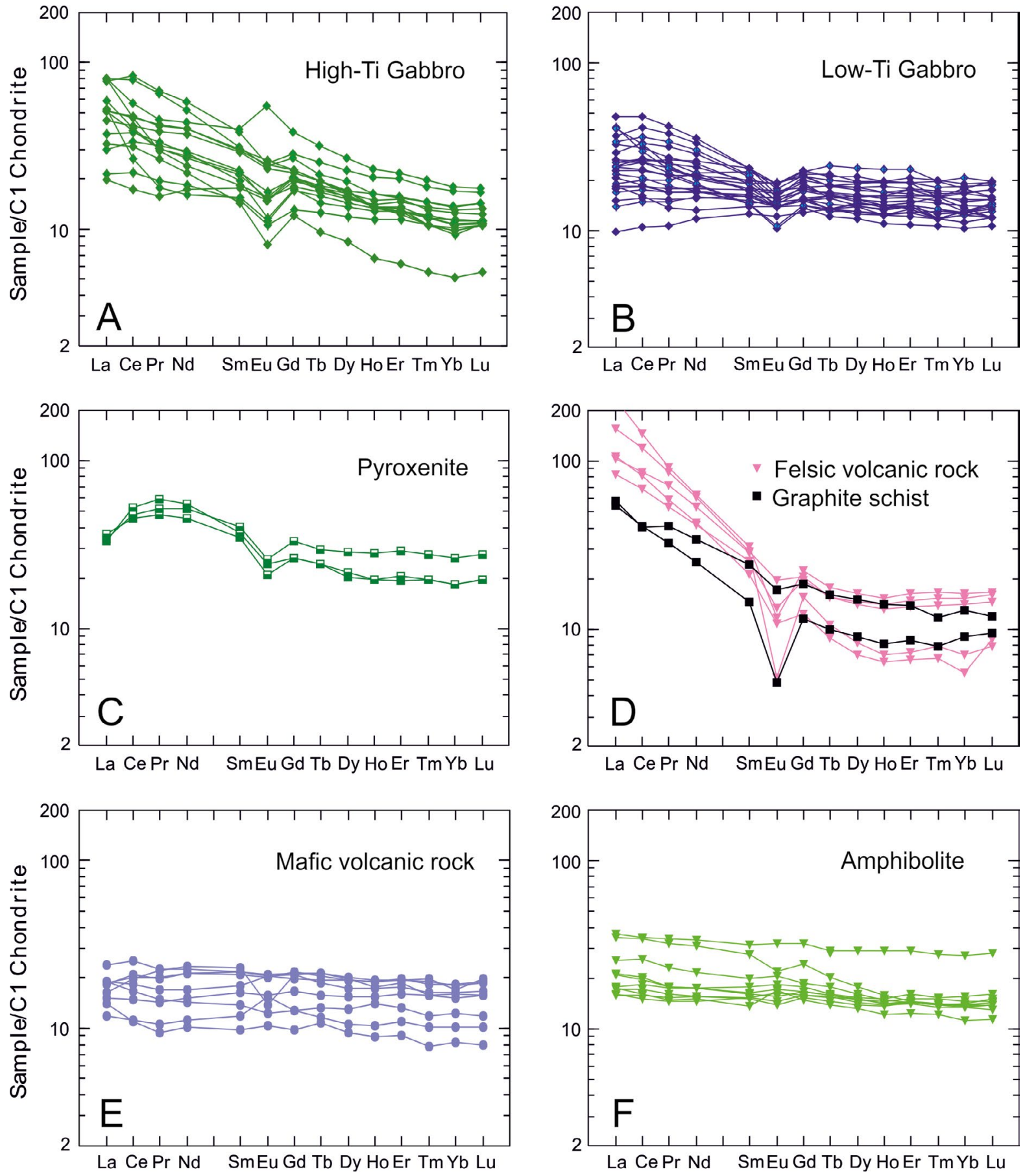

Figure 6. Chondrite-normalized REE patterns for various rock types from the Hietakero area. a) High-Ti gabbros, b) LowTi gabbros, c) Pyroxenites, d) Felsic volcanic rocks and graphite schist, e) Mafic volcanic rocks, and f) Amphibolites See also Fig. 5a for High-Ti and Low-Ti gabbros. 
Table 2. Co, $\mathrm{Cu}, \mathrm{Ni}, \mathrm{S}$ and precious metal and metal ratios form the Hietakero mineralization.

\begin{tabular}{|c|c|c|c|c|c|}
\hline Sample & L12090228 & L12090244 & L12090260 & L07006930 & L16027790 \\
\hline Rock type & Hybrid 1 & Hybrid 2 & Felsic volcanic & Scapolite gabbro & Pyroxenite \\
\hline Core/depth & $\mathrm{R} 10 / 174.80$ & $\mathrm{R} 10 / 190.80$ & R10/208.6 & R10/272.35 & R31/146.80 \\
\hline Auppb & 21.3 & 16.1 & 25.3 & b.d. & b.d. \\
\hline $\mathrm{Pd}$ & 29.6 & b.d. & 54.6 & 188 & 191 \\
\hline Pt & b.d. & b.d. & 13.1 & 146 & 40 \\
\hline Co $\%$ & 0.09 & 0.06 & 0.1 & 0.002 & 0.08 \\
\hline $\mathrm{Ni}$ & 0.21 & 0.17 & 0.25 & 0.004 & 0.26 \\
\hline $\mathrm{Cu}$ & 0.33 & 0.4 & 0.19 & 0.004 & 0.83 \\
\hline S & 15.3 & 10 & 15.8 & 0.18 & 15.8 \\
\hline $\mathrm{Ni} / \mathrm{Cu}$ & 0.6 & 0.4 & 1.3 & 0.98 & 0.3 \\
\hline $\mathrm{Ni} / \mathrm{Co}$ & 2.3 & 2.8 & 2.5 & 2.9 & 3.3 \\
\hline
\end{tabular}

* Note: Loss on ignition was not determined. b.d. = below detection limit

Overall, Fig. 7 demonstrates that base metals are incorporated into sulfides and silicate-bound $\mathrm{Ni}$ or Co are largely missing. It is also noteworthy that the samples of felsic volcanic rocks recovered from the drill cores show indistinguishable base metal characteristics from those of the Hietakero intrusion rocks (Fig. 7).

Figures $7 \mathrm{a}-\mathrm{b}$ show that $\mathrm{Ni}$ and Co correlate well with $S$, but also show two observable trends caused by the mineralization types (i.e., pyrrhotitedominant vs. pyrite-dominant types). Figures $7 d-f$ illustrate poor correlations between $\mathrm{Cu}$ and $\mathrm{Ni}$ and between $\mathrm{Cu}$ and $\mathrm{Co}$. It also indicates that the Hietakero mineralization may contain significant $\mathrm{Cu}$ grades ( $>0.3$ wt.\%) without significant $\mathrm{Co}$ $(<400 \mathrm{ppm})$ and $\mathrm{Ni}(<2000 \mathrm{ppm})$ grades. The $\mathrm{Ni} / \mathrm{Cu}$ ratio is less than 2 and typically less than 1 , and $\mathrm{Ni} / \mathrm{Co}$ varies commonly from 1 to 4 , being normally between 2 and 3 in mineralized samples. The $\mathrm{Ni} / \mathrm{Cu}$ ratio is also slightly higher $(>2.5)$ in mineralized pyroxenites compared to mineralized hybrid and felsic volcanic rocks (Fig. 4).

Addition of metals from external source (via country rock contamination or post-magmatic hydrothermal processes) is manifested by elevated $\mathrm{Mo}, \mathrm{Zn}$ and $\mathrm{Pb}$ contents (cf. Peltonen, 1995; Menard et al., 1996). In mineralized rocks (drill cores R10 and R31), Zn locally attains concentrations between 400 and 2000 ppm, Mo between 10 to $30 \mathrm{ppm}$ and $\mathrm{Pb}$ (100 to $4000 \mathrm{ppm}$ ), whereas sulfide-bearing black schist in drill cores shows much lower concentrations (Mo $<10 \mathrm{ppm}$, $\mathrm{Zn}<50 \mathrm{ppm}$ and $\mathrm{Pb}<100 \mathrm{ppm})$. In addition, few samples from thin skarn-type horizons and the felsic volcanic formation also yielded elevated $\mathrm{Zn}$ contents (up to $2000 \mathrm{ppm}$ ).

The average metal tenors in the Hietakero deposit are 0.55 wt. $\%$ for $\mathrm{Ni}, 1.07$ wt. $\%$ for $\mathrm{Cu}$ and 0.23 wt.\% for Co. As illustrated in Fig. 8a, they are clearly lower than those in many economically important mafic to ultramafic rock-hosted Ni-Cu-PGE sulfide deposits globally. This is particularly true for $\mathrm{Ni}$, which generally shows a tenor of less than $1.0 \mathrm{wt} . \%$ at Hietakero. The metal contents of the sulfide phase seem to have no clear correlation with the host rock types, including gabbros, pyroxenites, various hybrid rocks, and felsic volcanic rocks. In individual samples, the $\mathrm{Ni}$ tenor varies less than that of $\mathrm{Cu}$, which is consistent with the tendency of $\mathrm{Cu}$ to be a more mobile element. In rare cases, the $\mathrm{Cu}$ tenor reaches several wt. $\%$, being generally lower than $2.0 \mathrm{wt} . \%$; this seems to be intermediate between the $\mathrm{Cu}$ tenors of Archean komatiite-hosted sulfide deposits and other $\mathrm{Ni}-\mathrm{Cu}$-PGE deposits globally.

A special feature of the Hietakero sulfide deposit, the relatively high $\mathrm{Co}$ content compared to $\mathrm{Ni}$ and $\mathrm{Cu}$, is evident in Fig. 8b, where analyses of the Hietakero sulfide-bearing samples are compared with average compositions of several other $\mathrm{Ni}-\mathrm{Cu}$-PGE deposits globally. In the former, the $100 \mathrm{xCo} /(\mathrm{Ni}+\mathrm{Cu}+\mathrm{Co})$ values (Co\#) fall mostly in 

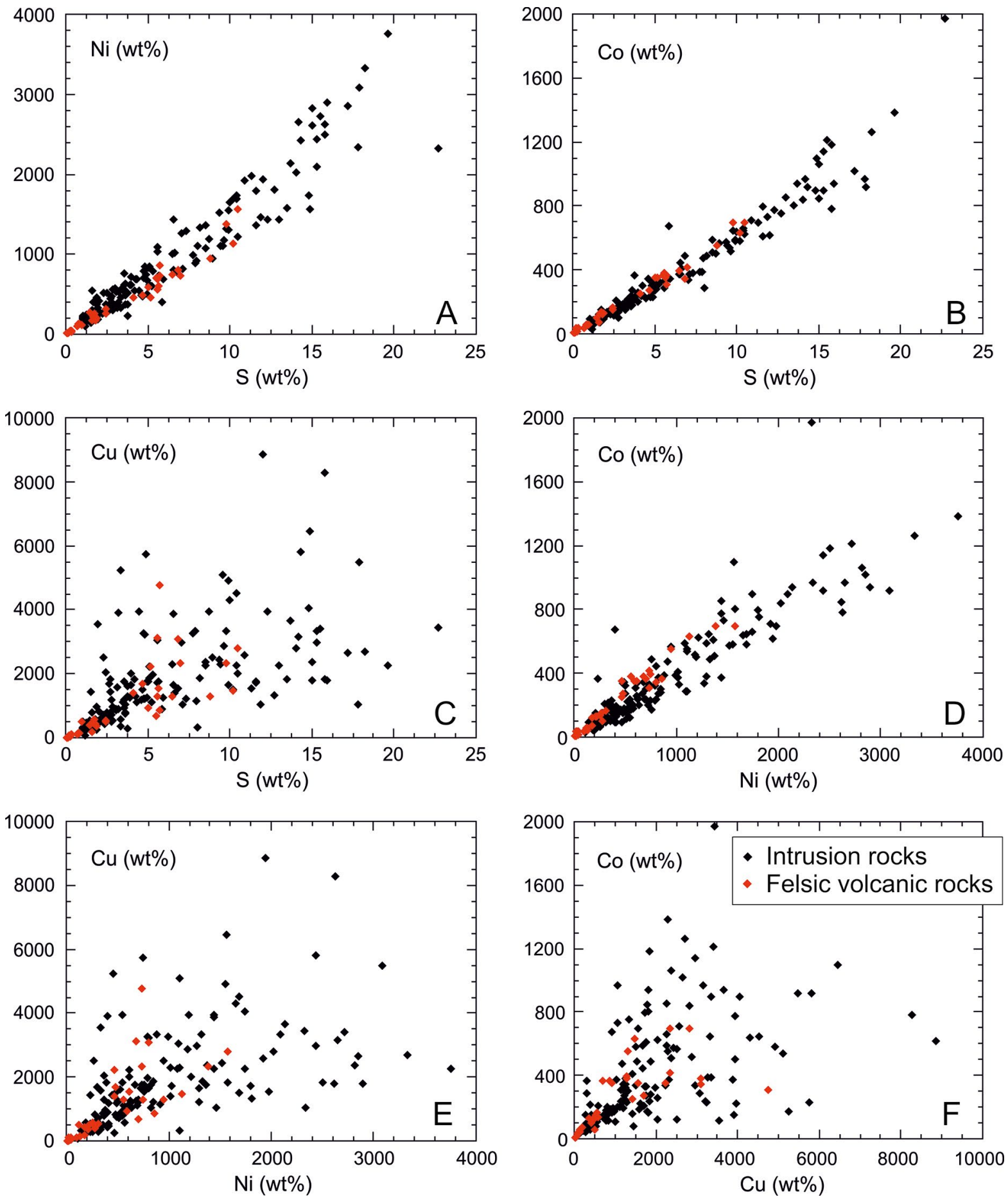

Figure 7. Chalcophile element concentrations in Hietakero mineralized rocks (intrusion rocks include gabbroic to pyroxenitic cumulates and hybrid rocks). a) S (wt.\%) vs. Ni (wt.\%), b) S (wt.\%) vs. Co (wt.\%), c) S (wt.\%) vs. Cu (wt.\%), d) $\mathrm{Ni}($ wt.\%) vs. Co (wt.\%), e) Ni (wt.\%) vs. Cu (wt.\%), and f) Cu (wt.\%) vs. Co (wt.\%). 

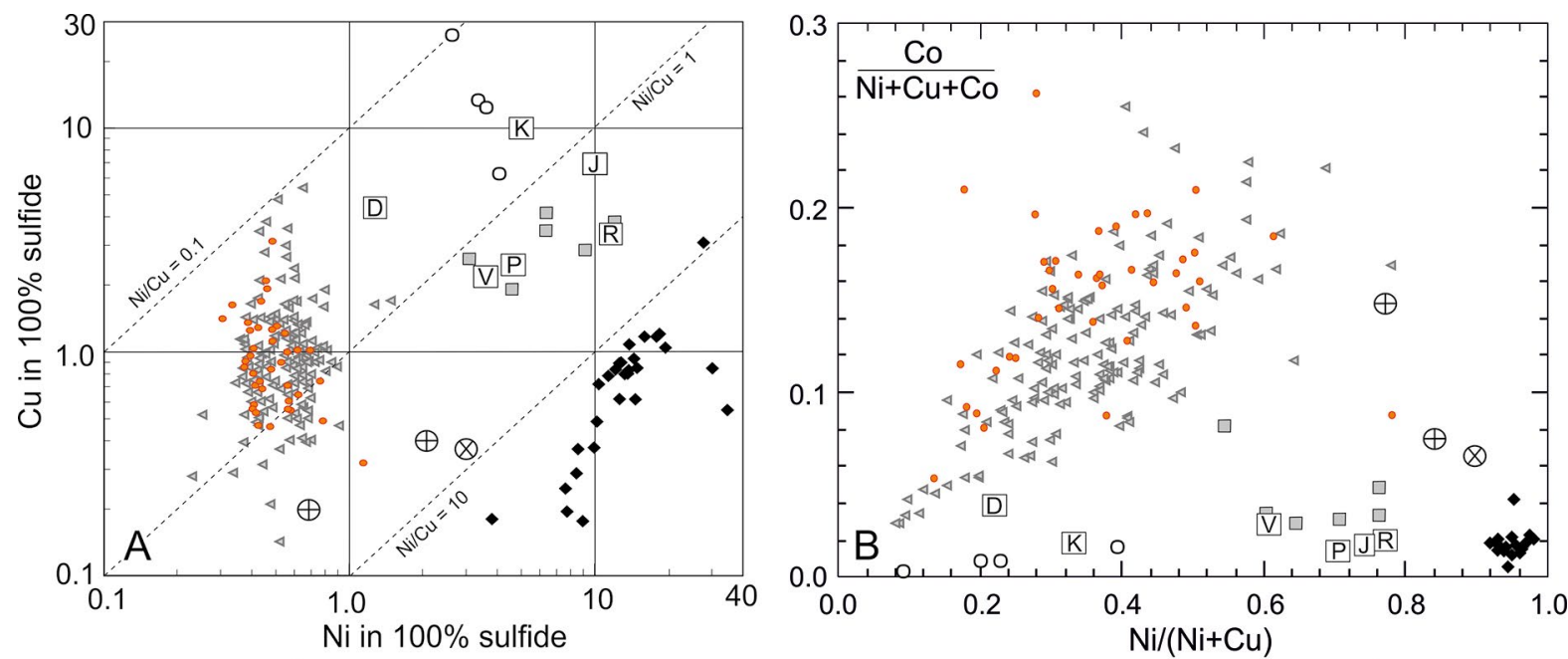

$\begin{array}{lllll}\text { - Archean komatiites } & \mathrm{D} \text { Duluth } & \mathrm{P} \text { Pechenga } & \bigotimes \text { Kabanga North } & \text { Hietakero } \\ \square \text { Svecofennian } & \mathrm{J} \text { Jinchuan } & \mathrm{R} \text { Raglan } & \oplus \text { Kabanga Main } & \triangleleft \text { Gabbro, pyroxenite, hybrid rock } \\ \text { O Noril'sk } & \mathrm{K} \text { Kevitsa } & \mathrm{V} \text { Voisey's Bay } & & \text { - Felsic volcanic rock }\end{array}$

Figure 8. Nickel and copper tenors (a) and metal ratios (b) in mineralized samples from Hietakero deposit, classified based on their host rock, and average metal tenors of different Ni-Cu-PGE ore types globally. Comparative data taken from Isohanni et al. (1985), Papunen \& Koskinen (1985), Naldrett (1989, 2004), Mutanen (1997), Theriault \& Barnes (1998), Seat et al. (2004), Lamberg (2005), Barnes \& Lightfoot (2005), Lesher \& Barnes (2009), and Maier \& Barnes (2010).

the range of 5-20 and average at 12 . This is clearly elevated as in general, magmatic $\mathrm{Ni}-\mathrm{Cu}$ deposits show Co\# values of less than 5 (e.g., Czamanske et al., 1992; Barnes et al., 2001; Naldrett, 2004; Lesher $\&$ Barnes, 2009). Cobalt enrichment can also be expressed in terms of $\mathrm{Ni} / \mathrm{Co}$, which averages 2.6 at Hietakero whereas in the reference data (op.cit), it is commonly between 15 and 75 .

The Hietakero mineralization has low concentrations of platinum group elements (PGE). The total Pd+Pt content falls commonly below $100 \mathrm{ppb}$ and has a poor correlation with $S$ in mineralized hybrid and felsic volcanic rocks in drill core R10. Slightly elevated concentrations were detected in one drill core (R10) outside the proper mineralized zone, where poorly-mineralized $(<3000 \mathrm{ppm} \mathrm{S})$ gabbroic cumulates yielded 100-350 ppb Pd+Pt. The highest concentrations of $\mathrm{Pd}+\mathrm{Pt}(\sim 100-300$ $\mathrm{ppb}$ ) occur in mineralized pyroxenitic cumulates in drill core $\mathrm{R} 31$, where $\mathrm{Pd}+\mathrm{Pt}$ correlates rather well with the sulfur content, forming two distinct trends (low $S$ and high $S$ ) in Figs. 9b. The samples of the
low-S trend are slightly enriched in Pt compared to those of the high-S trend, and palladium correlates rather well with platinum, but correlation with $\mathrm{Pt}$ and $S$ is weak in drill core R31. In both mineralized drill cores (R10 and R31), Pt/Pd varies between 0.2 and 0.8 . It seems that the behavior of $\mathrm{Pd}+\mathrm{Pt}$ is different in different sections of the intrusion as samples from drill cores R31 and R10 plot on different trends on a Pd+Pt vs. S diagram (Figs. 9ab) and plots of $S$ vs. Pd and Pt (not shown). Gold concentrations are very low in both mineralized drill cores ( $\leq 30 \mathrm{ppb}$ ), and As and Sb show no elevated concentrations (Te and Bi were not analyzed).

In Fig. 10, the base metal and precious metal relations of the Hietakero deposit are compared with those of other mafic-ultramafic rock-related $\mathrm{Ni}$-Cu-PGE deposits. As in the case of the Kevitsa (main ore) and Duluth deposits, $\mathrm{Cu}$ is more abundant than $\mathrm{Ni}$ in the Hietakero deposit, with the $\mathrm{Ni} /(\mathrm{Ni}+\mathrm{Cu})$ ratio being 0.34 on average. In terms of PGE depletion relative to base metals, the Hietakero deposit is comparable to the Pechenga and Jinchuan 

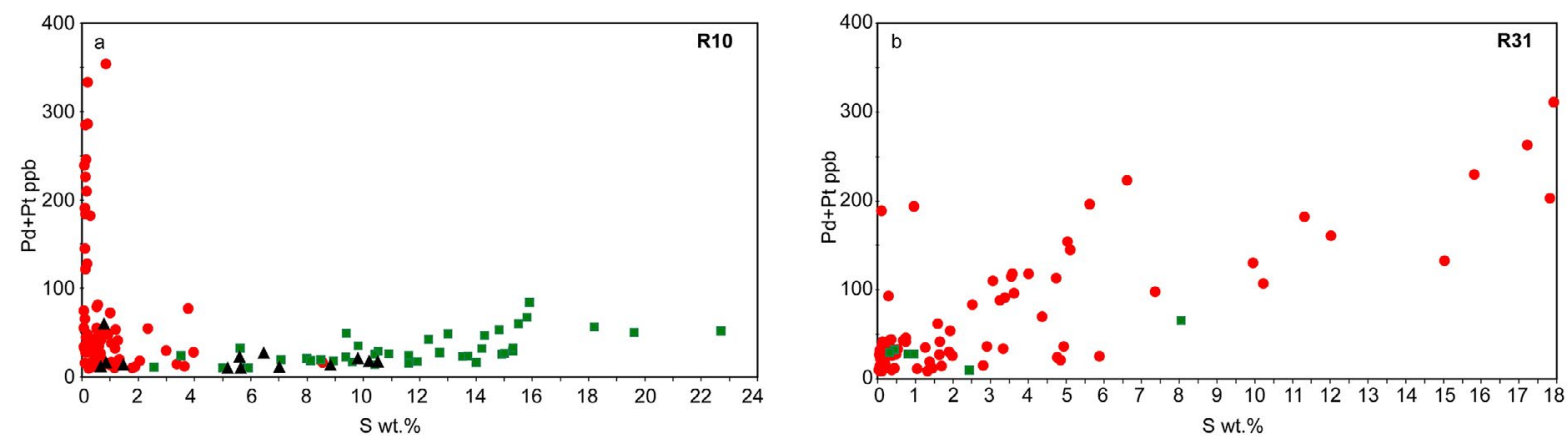

Hybrid rocks

Felsic volcanic rock

Gabbroic to pyroxenitic cumulates

Figure 9. S vs. Pd+Pt diagram for mineralized rock samples from drill cores R10 (a) and R31 (b). Locations of the drill holes shown in Fig. 2.

Figure 10. Average $\mathrm{Cu} /(\mathrm{Pt}+\mathrm{Pd})$ and $\mathrm{Ni} /(\mathrm{Pt}+\mathrm{Pd})$ ratios in different magmatic Ni-Cu-PGE deposits. Also shown are lines corresponding to $\mathrm{Ni} /(\mathrm{Ni}+\mathrm{Cu})$ ratios between 0.1 and 0.95 . The two compositions from Kevitsa represent normal ore (upper) and Ni-PGE ore (lower). Literature data taken from Mutanen (1997), Naldrett (2004), Konnunaho et al. (2015), and Törmänen et al. (2016).

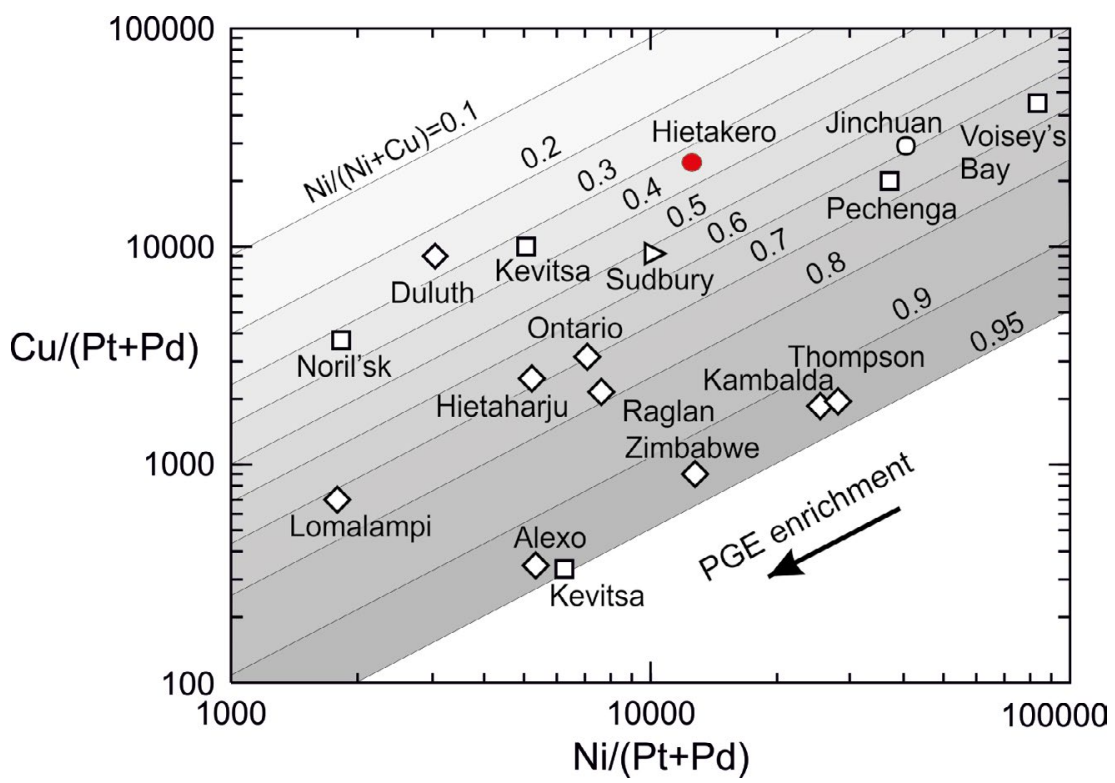

Ni-Cu-PGE deposits. However, Fig. 10 shows that the metal relations are quite unique in the Hietakero deposit.

\section{Sulfur isotope data}

Two sulfide-bearing pyroxenite samples from the Hietakero intrusion and two country-rock samples, one graphite-sulfide schist and one felsic volcanic rock from the Vikkuri Formation, were analyzed for sulfur isotopes. In-situ isotope analyses were conducted on pyrrhotite, pyrite, and chalcopyrite. The analytical results are listed in Table 3 and illustrated in Fig. 11. The obtained $\delta^{34} S$ values indicate that the three rock types display distinct sulfur isotope compositions. The black schist shows the lightest $S$ isotope composition, with the four analyzed pyrrhotite grains having an identical $\delta^{34} S$ value of -10.9. Chalcopyrite and pyrite grains from one pyroxenite sample yielded an average $\delta^{34} S$ value of $-0.1 \pm 0.9 \%$ o (1s), and pyrrhotite and 


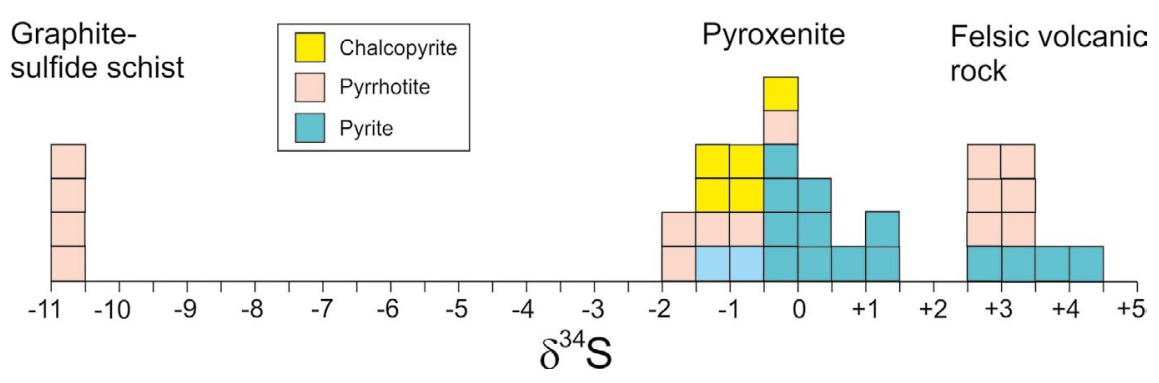

Figure 11. Sulfur isotope compositions of sulfide minerals in ore-bearing pyroxenites from the Hietakero intrusion and in its country rock samples. Each box represents one sulfur isotope analysis.

pyrite grains from the other pyroxenite sample gave an average $\delta^{34} S$ value of $-0.7 \pm 0.7 \%$ o (1s), with the compositions falling into the supposed mantle $\delta^{34} S$ range of -2 to $+2 \%$ o (Ripley $\& \mathrm{Li}, 2003$ ). As seen from Fig. 9, pyrite in these two samples tend to yield slightly higher ${ }^{34} \mathrm{~S} /{ }^{32} \mathrm{~S}$ ratios compared to pyrrhotite or chalcopyrite. Pyrrhotite and pyrite from the felsic volcanic rock sample show the heaviest sulfur isotope compositions, with $\delta^{34} S$ averaging $+3.1 \pm 0.5 \%$.

\section{Discussion}

Several types of economically important orthomagmatic $\mathrm{Ni}-\mathrm{Cu}-\mathrm{Co}-\mathrm{PGE}$ sulfide deposits are located in Finland (Makkonen et al., 2017). Most of them are typical mafic to ultramafic rockhosted Ni-Cu-PGE deposits. Compared to 'classic' $\mathrm{Ni}-\mathrm{Cu}$ sulfide deposits, the Hietakero deposit shows relatively high concentrations of Co at given $\mathrm{Ni}$ and $\mathrm{Cu}$ levels. The total metal tenor is not high, averaging 1.85 wt. $\%$ of $\mathrm{Ni}+\mathrm{Cu}+\mathrm{Co}$. However, taking into account the price differences of the metals and calculating all metals as $\mathrm{Cu}$ equivalents, this average corresponds to 3.1-4.2 wt.\% of $\mathrm{Cu}$, depending on whether the current exceptionally high Co price or a more conservative 5-year average value is used.

\subsection{Parental magma composition and magmatic cobalt enrichment}

The estimation of the parental magma composition of the Hietakero deposit is difficult, because the rocks have undergone strong hydrothermal alteration (e.g., scapolitization and albitization). In addition, primary silicate minerals, such as olivine and pyroxenes, were not found. Nevertheless, the apparent absence of olivine-bearing cumulates and the dominance of gabbroic rocks in the intrusion suggest an evolved basaltic parental magma. As shown in Fig. 8, the mineralized samples at Hietakero are characterized by a low Ni tenor, low $\mathrm{Ni} / \mathrm{Cu}$ and high $\mathrm{Co} /(\mathrm{Ni}+\mathrm{Cu}+\mathrm{Co})$ and are markedly different from deposits from komatiitic systems, being indicative of a more evolved basaltic system. In addition, the low PPGE concentrations in the Hietakero deposit support an evolved parental magma type (Figs. 8 and 9).

The $\mathrm{Ni} / \mathrm{Cu}$ ratio varies a lot due to the mobility of $\mathrm{Cu}$ and hence there is some uncertainty on the original $\mathrm{Ni} / \mathrm{Cu}$ ratio of the sulfide phase. In contrast, $\mathrm{Ni}$ and Co show a more consistent behavior and a good mutual positive correlation, yielding an average $\mathrm{Ni} / \mathrm{Co}$ ratio of $2.6 \pm 0.7(1 \sigma)$. This ratio is unusually low and needs an explanation. The 
Table 3. In-situ $\delta 34 S \%$ analyses from mineralized samples and surrounding country rocks from the Hietakero deposit.

\begin{tabular}{|c|c|c|c|c|}
\hline Rock Type & Sample & Analyzed sulfide & б34S \% CDT & $2 \sigma$ \\
\hline Sulfide bearing graphite schist & 160351 & Pyrrhotite & -10.85 & 0.17 \\
\hline Sulfide bearing graphite schist & 160351 & Pyrrhotite & -10.86 & 0.18 \\
\hline Sulfide bearing graphite schist & 160351 & Pyrrhotite & -10.87 & 0.16 \\
\hline Sulfide bearing graphite schist & 160351 & Pyrrhotite & -10.92 & 0.18 \\
\hline Pyroxenite & 160369 & Chalcopyrite & -1.5 & 0.2 \\
\hline Pyroxenite & 160369 & Chalcopyrite & -1.3 & 0.2 \\
\hline Pyroxenite & 160369 & Pyrite & -0.3 & 0.1 \\
\hline Pyroxenite & 160369 & Pyrite & -0.5 & 0.1 \\
\hline Pyroxenite & 160369 & Chalcopyrite & -0.2 & 0.2 \\
\hline Pyroxenite & 160369 & Chalcopyrite & -0.6 & 0.2 \\
\hline Pyroxenite & 160369 & Pyrite & 0.8 & 0.1 \\
\hline Pyroxenite & 160369 & Pyrite & 0.3 & 0.1 \\
\hline Pyroxenite & 160369 & Pyrite & 1.3 & 0.1 \\
\hline Pyroxenite & 160369 & Pyrite & 1.0 & 0.1 \\
\hline Pyroxenite & 160432 & Pyrrhotite & -1.5 & 0.2 \\
\hline Pyroxenite & 160432 & Pyrrhotite & -1.8 & 0.2 \\
\hline Pyroxenite & 160432 & Pyrite & -0.2 & 0.2 \\
\hline Pyroxenite & 160432 & Pyrite & 0.3 & 0.2 \\
\hline Pyroxenite & 160432 & Pyrrhotite & -1.0 & 0.2 \\
\hline Pyroxenite & 160432 & Pyrrhotite & -0.6 & 0.2 \\
\hline Pyroxenite & 160432 & Pyrite & -0.8 & 0.1 \\
\hline Pyroxenite & 160432 & Pyrite & -0.3 & 0.1 \\
\hline Pyroxenite & 160432 & Pyrrhotite & -0.1 & 0.2 \\
\hline Pyroxenite & 160432 & Pyrrhotite & -1.6 & 0.2 \\
\hline Pyroxenite & 160432 & Pyrite & -1.1 & 0.2 \\
\hline Pyroxenite & 160432 & Pyrite & 0.3 & 0.2 \\
\hline Felsic volcanic & 160434 & Pyrrhotite & 2.9 & 0.2 \\
\hline Felsic volcanic & 160434 & Pyrrhotite & 3.0 & 0.2 \\
\hline Felsic volcanic & 160434 & Pyrite & 2.7 & 0.2 \\
\hline Felsic volcanic & 160434 & Pyrite & 3.5 & 0.1 \\
\hline Felsic volcanic & 160434 & Pyrite & 3.3 & 0.2 \\
\hline Felsic volcanic & 160434 & Pyrite & 4.3 & 0.2 \\
\hline Felsic volcanic & 160434 & Pyrrhotite & 3.1 & 0.2 \\
\hline Felsic volcanic & 160434 & Pyrrhotite & 2.7 & 0.2 \\
\hline Felsic volcanic & 160434 & Pyrrhotite & 3.0 & 0.2 \\
\hline Felsic volcanic & 160434 & Pyrrhotite & 2.6 & 0.2 \\
\hline
\end{tabular}


first option to consider below is that high Co is magmatic in origin and related to crystal fractionation of the parental melt.

Before discussing the hypothesis of magmatic enrichment of cobalt, it needs to be pointed out that although cobaltian pentlandite is most commonly found in hydrothermally produced or hydrothermally altered sulfide-bearing rocks (e.g., Kouvo et al., 1959; Borodaev et al., 2007), experimental studies have shown that pentlandite and cobalt pentlandite form a continuous solid solution at magmatic temperatures, allowing cobaltian pentlandite to be formed from monosulfide solid solution (mss) in magmatic $\mathrm{Ni}-\mathrm{Cu}$ sulfide deposits, provided sufficient cobalt is present (Kitakaze \& Sugaki, 2004). This is also evidenced by studies reporting of the presence of cobaltian pentlandite in sulfide assemblages interpreted as magmatic in origin (e.g., Brickwood, 1986; Garuti et al., 1986; Miller and Cervantes, 2002; Pinto et al., 2015). These also include sulfide assemblages in the upper zone of the Bushveld Complex where crystal fractionation led to residual liquids with high $\mathrm{Co} / \mathrm{Ni}$ (Merkle \& von Gruenewaldt, 1986). It is thus feasible that the cobaltian pentlandite in the Hietakero mineralization is part of the magmatic sulfide assemblage.

Of the main silicate minerals, olivine has the greatest capacity to fractionate the $\mathrm{Ni} / \mathrm{Co}$ ratio in a silicate melt as its mineral/melt distribution coefficient is clearly higher for Ni compared to Co $\left(\mathrm{D}_{\mathrm{Ni}}^{\mathrm{O} / / \text { melt } / \mathrm{D}_{\mathrm{Co}} \mathrm{O} / \text { melt }} 2-3\right.$; Bédard, 2005). Given the evolved nature of the magma at Hietakero, one could argue that extensive olivine fractionation in a staging magma chamber has decreased $\mathrm{Ni} / \mathrm{Co}$ in the residual melt from which the mineralization was later formed. To test the efficiency of this process, model calculations of fractional crystallization of olivine were performed using the Raleigh distillation equation incrementally with small steps a typical komatiitic basalt with 18 wt.\% $\mathrm{MgO}$, 690 ppm Ni and 82 ppm Co (Ni/Co 8.4) as a starting melt composition. The olivine/melt distribution of $\mathrm{Ni}$ was adjusted according to the $\mathrm{MgO}$ content of the evolving melt using the equation:
$\mathrm{D}_{\mathrm{Ni}}^{\mathrm{Ol} / \mathrm{melt}}=115 / \mathrm{MgO}($ wt.\%) -2.1 (Arndt, 1977) [1]

and the value of $\mathrm{D}_{\mathrm{Co}}{ }^{\mathrm{O} / \text { melt }}$ was assumed to be $0.33 \times \mathrm{D}_{\mathrm{Ni}}^{\mathrm{Ol} / \mathrm{melt}}$ (Gaetani \& Grove, 1992; Dwarzski \& Herd, 2003).

As indicated in Fig. 12, when the Ni content of the residual melt has dropped down to about $100 \mathrm{ppm}$, the $\mathrm{Ni} / \mathrm{Co}$ ratio has decreased down to around 2.0, i.e. the melt composition has changed significantly in terms of $\mathrm{Ni} / \mathrm{Co}$. However, as $\mathrm{Ni}$ is clearly more

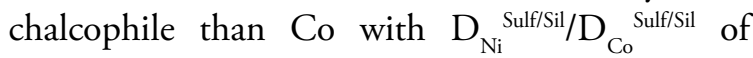
13-17 (e.g., Kiseeva and Wood, 2013, 2015; Li, 2014), a sulfide melt in equilibrium with a silicate melt will acquire much higher $\mathrm{Ni} / \mathrm{Co}$ than the latter. Figure 12 illustrates the variation of the $\mathrm{Ni}$ and $\mathrm{Co}$ tenors in sulfides that are in equilibrium with the modelled silicate liquids in their various stages of fractionation, assuming the silicate/sulfide liquids mass ratios ( $\mathrm{R}$ factors) to be between 50 and 200 . The modeling was conducted using the following equation (Campbell \& Barnes, 1984):

$$
\mathrm{Y}=\mathrm{X}_{\mathrm{o}} \mathrm{D}^{\text {Sulf/Sil }} \mathrm{R} /\left(\mathrm{R}+\mathrm{D}^{\text {Sulf/Sil }}\right)[2]
$$

in which $\mathrm{Y}$ is the concentration of a metal in the sulfide melt, $\mathrm{X}_{\mathrm{o}}$ is the initial concentration of a metal in the silicate melt, $\mathrm{R}$ is the mass ratio of silicate to sulfide, and $\mathrm{D}^{\text {Sulf/Sil }}$ is the sulfide melt/silicate melt distribution coefficient. The calculated sulfide compositions deviate significantly from the average Hietakero sulfide in having higher $\mathrm{Ni} / \mathrm{Co}$ and in most cases much higher $\mathrm{Ni}$. Increasing the value of the $\mathrm{R}$ factor makes the match even worse.

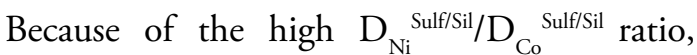
separation of sulfides from a silicate melt would be even more efficient than olivine fractionation in decreasing Ni/Co in the silicate melt. As another mechanism to produce low Ni/Co sulfides similar to those found at Hietakero, we modeled the case where two different magmas (207 and 100 ppm $\mathrm{Ni}$ and 62 and 50 ppm Co, respectively), labeled $A$ and $B$ in Fig. 12, equilibrated with 0.4 wt.\% of sulfides in a staging magma chamber. Later the resultant chalcophile element-depleted magmas, 


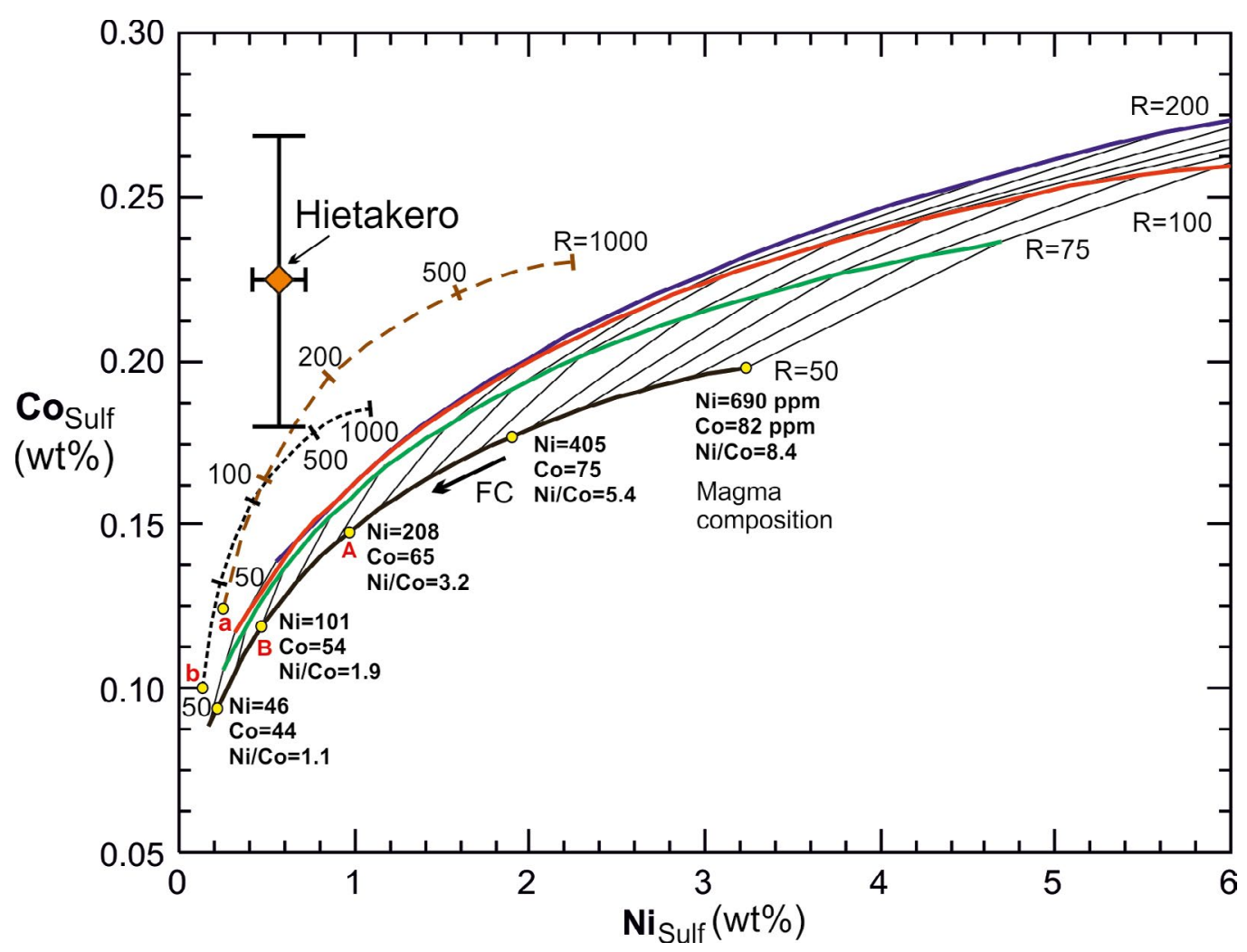

Figure 12. Average composition of Hietakero sulfides compared with model sulfide compositions generated by sulfide segregation at different $R$ factor values, with silicate melts varying in composition from komatiitic basalt to basalt. Different magma compositions were calculated after variable degrees of olivine fractionation, starting with a melt composition with MgO $18 \mathrm{wt} . \%$, Ni $690 \mathrm{ppm}$ and Co $82 \mathrm{ppm}$. Dashed lines represent sulfide segregations at R factors between 50 and 1000 from two melts, $a$ and $b$, which had undergone earlier equilibration with $0.4 \%$ of sulfide (the original silicate melt compositions were A and B). The following D values were used: DNiSulf/Sil $=700$, DCoSulf/Sil $=46.7$ (DNiSulf/Sil/DCoSulf/Sil = 15), DNiOl/melt = 115/MgO (wt.\%) - 2.1 (Arndt, 1977), DCoOl $/ \mathrm{melt}$ $=0.33 \mathrm{DNiOl} / \mathrm{melt}$. Sulfide melt compositions at different $\mathrm{R}$ factor values were calculated using the equation given by Campbell and Barnes (1984). See text for more details.

marked $\mathrm{a}$ and $\mathrm{b}$ in Fig. 12, were involved in sulfide ore formation with $\mathrm{R}$ factors varying from 50 to 1000 , as shown by the dashed lines in Fig. 12 . The first sulfide saturation stage would strip the magma from platinum-group elements, which is consistent with the observed low PGE levels at Hietakero. The second sulfide saturation stage would create sulfides with lower $\mathrm{Ni} / \mathrm{Co}$ than in the compositions obtained in the first model, but still they hardly reach the field of the Hietakero sulfides and regardless of the $\mathrm{R}$ factor, stay clearly below the average Hietakero sulfide composition (Fig. 12). One problem with the two-stage model is that in order to produce low-Ni/Co sulfide, the silicate melt tends to become depleted in $\mathrm{Ni}, \mathrm{Cu}$ and $\mathrm{Co}$, with its capacity to generate $\mathrm{Ni}-\mathrm{Cu}-\mathrm{Co}$ mineralization drastically diminishing.

On the basis of modelling and above discussion, we conclude that normal fractional crystallization in an ultramafic-mafic magmatic system or earlier sulfide segregation cannot explain the extremely low $\mathrm{Ni} / \mathrm{Co}$ ratio in the Hietakero mineralization. This leaves us with three other potential explanations: 1) The parental magma was intrinsically elevated in Co, potentially due to abnormally high Co in its mantle source, but this hypothesis is difficult to 
test; 2) The magma assimilated Co and other metals, including $\mathrm{Zn}, \mathrm{Mo}$, and $\mathrm{Pb}$, from a metal- and sulfur-bearing country rock, such as black shale or a hidden base metal-bearing sulfide mineralization; 3) Enrichment in Co, $\mathrm{Zn}, \mathrm{Mo}$, and $\mathrm{Pb}$ is due to post-magmatic hydrothermal processes that were also responsible for the intensive scapolitization and albitization in the area.

\subsection{Contamination}

As discussed above, olivine or sulfide fractionation hardly produced a magma with sufficiently high $\mathrm{Co} / \mathrm{Ni}$, but still the magma could have had a high $\mathrm{Co} / \mathrm{Ni}$ ratio via assimilation of Co-bearing country rock material. The occurrence of hybrid rocks at Hietakero provides clear evidence for interaction of mafic magma with surrounding country rocks. In addition, the anomalously high concentrations of $\mathrm{Zn}, \mathrm{Mo}$ and $\mathrm{Pb}$ in the Hietakero mineralized rocks are potential indications for country rock assimilation and/or addition of metals by hydrothermal processes in the magmatic stage (e.g., Peltonen, 1995; Menard et al., 1996). An example of the case where assimilation of country rock sedimentary material by mafic magma has resulted in enrichment of $\mathrm{Co}, \mathrm{Zn}$ and Mo in sulfide mineralization is described by Garuti et al. (1986) from the Ivrea-Verbano basic complex, Italy. This reaction together with depletion of $\mathrm{Ni}$ by former crystal fractionation contributed to the generation of sulfides with an average $\mathrm{Co} / \mathrm{Ni}$ ratio of 0.19 , a value that approaches the lowest values measured from Hietakero.

The importance of S-bearing country rocks in the genesis of orthomagmatic sulfide deposits has been highlighted in several studies, with supporting evidence coming particularly from $S$ isotope compositions of the ores (e.g., Lesher \& Groves, 1986; Li et al., 2001; Ripley and Li, 2003; Arndt et al., 2005; Keays \& Lightfoot, 2010). However, some deposits (e.g., Jinchuan, Tang et al., 2009; Nebo-Babel, Seat et al., 2009; Voisey's Bay, Ripley et al., 2002) show $\delta^{34} S$ values that are near the assumed mantle value. These values have been explained by several mechanisms: 1) addition of volatiles (e.g., $\mathrm{CO}_{2}$ and $\mathrm{H}_{2} \mathrm{O}$ ) (e.g., Ripley et al., 2002; Park et al., 2004, Liu et al., 2007; Tomkins et al., 2012), 2) assimilation of siliceous country rock (S-poor) material and isotope homogenization (e.g., Ripley et al., 2002; Seat at al., 2009), 3) mixing of magmas of varying composition ( $\mathrm{Li}$ and Ripley, 2005; Ripley and Li, 2013), and 4) significant fractional crystallization (e.g., Park et al., 2004; Li and Ripley, 2005; Ripley and Li, 2013). Most of these mechanisms may reduce the solubility of sulfur, but only have a limited potential to result in sulfur saturation and significant ore formation in high-Mg systems, such as komatiites, though can possibly lead to sulfur saturation in more basaltic compositions (e.g., MacLean, 1969; Li et al., 2001; Ripley \& Li, 2013). In addition, a sulfur( \pm metal) source of unknown $\delta^{34} S$ may exist at depth (e.g., at a sub-chamber level). In the case of the Hietakero mineralization, fractional crystallization at a deeper level in the crust (e.g., crystallization of olivine) and assimilation/incorporation of crustal rocks have possibly reduced the $S$ solubility of the Hietakero parental magma significantly and only a limited amount of external $S$ was needed to reach S saturation.

The Hietakero deposit is very sulfur rich, which shows that external $S$ was involved. In the Hietakero area, the sulfide-bearing black schists and/or rather sulfide-poor felsic tuffogeneous rocks of the Vikkuri Formation form the most potential external sulfur sources. In-situ $\delta^{34} S$ determinations show that the isotope compositions of Hietakero deposit sulfides (pyrrhotite, pyrite and chalcopyrite) deviate slightly from the assumed mantle values ( -2 to $+2 \%$; Ripley and Li, 2003), varying from -2 to $+1.5 \%$ in mineralized pyroxenites and from +2 to $+4.5 \%$ in mineralized felsic volcanic rocks. Sulfide-bearing black schist samples yielded much lighter isotope compositions with a small $\delta^{34} S$ range from -10.5 to $-11 \%$ (Fig. 11) and consequently, it seems that assimilation of sulfur from black shales did not play a significant role in the formation of the Hietakero mineralization. The sulfur isotope compositions of sulfide-bearing felsic volcanic rocks are only 
marginally heavier than those of the mineralized rocks of the Hietakero intrusion, suggesting that at least locally, crustal sulfur was added into the magmatic system, but this cannot explain the high $\mathrm{Co} / \mathrm{Ni}$ ratio in the latter. In addition, appropriate sulfur- and metal-rich ( $\mathrm{Co}, \mathrm{Zn}, \mathrm{Pb}$, and $\mathrm{Mo}$ ) sources are so far unknown in the Archean and Paleoproterozoic formations of the Käsivarsi region. To test the derivation of sulfur from a potential contaminant in the Archean bedrock, multiple sulfur isotope analyses should be used (cf. Bekker et al., 2009; Konnunaho et al., 2013).

\subsection{Post-magmatic modification}

Unique metal combination $\mathrm{Co}-\mathrm{Cu}-\mathrm{Ni}( \pm \mathrm{Zn}-\mathrm{Pb}-\mathrm{Mo})$ is not typical in orthomagmatic sulfide deposits, but such kind of combination may developed via hydrothermal processes in favorable environment and conditions.

Given the absence of primary silicates at Hietakero, which could be used to assess the cobalt content of the basaltic magma, we cannot exclude the possibility of introduction of cobalt and other metals during the metasomatic alteration of the Hietakero intrusion. As mobile metals, $\mathrm{Co}, \mathrm{Zn}, \mathrm{Pb}$, and Mo could have been added by post-magmatic hydrothermal processes related to intensive scapolitization and albitization. The mode of occurrence of sulfides as massive veins, veinlets, patches, and as brecciated to net-textured forms in the Hietakero deposit manifests their mobilization, possibly by post-magmatic hydrothermal processes related to scapolitization and albitization.

Post-magmatic alteration processes have had a significant impact on the Paleoproterozoic rocks in the study area. Similar alteration style involving albitization and scapolitization is widespread in the greenstone areas in the northern part of the Fennoscandian Shield (e.g., Frietsch et al., 1997 and references therein). Several mineral deposits, especially those of $\mathrm{Au}-\mathrm{Co}-\mathrm{Cu}$, are associated with such metasomatized rocks, including the Coenriched $\mathrm{Au}-\mathrm{Cu}-\mathrm{U}$ deposits in the Kuusamo belt (Pankka and Vanhanen, 1992; Vasilopoulos, 2015).
Similar post-magmatic hydrothermal processes as in the Kuusamo area may have contributed to Co ( \pm other metals) enrichment, redistribution of $\mathrm{Cu}$ and modification of LREE contents in the Hietakero deposit. However, at Hietakero, Au, $\mathrm{Ag}, \mathrm{U}$ and semimetals As and $\mathrm{Sb}$ are not elevated in a similar manner as in many hydrothermally modified deposits (e.g., Kuusamo-type deposits). In addition, although $\mathrm{Cu}$ is clearly mobilized, the good correlation between $\mathrm{Ni}$ and Co suggests a magmatic rather than hydrothermal control of these elements.

Based on the above discussion, enrichment of $\mathrm{Co}, \mathrm{Ni}$ and $\mathrm{Cu}$ is likely a magmatic phenomenon and other mobile metals ( $\mathrm{Zn}, \mathrm{Pb}$, and $\mathrm{Mo}$ ) were in the system in a magmatic stage and/or postmagmatic hydrothermal processes related to scapolitization and albitization. It is evident that hydrothermal fluids have remobilized and reconcentrated sulfides and metals of the Hietakero deposit.

\section{Conclusions}

1) The Hietakero mineralization represents a unique Co-enriched $\mathrm{Ni}$-Cu sulfide deposit type among the other more 'classic' $\mathrm{Ni}-\mathrm{Cu}$ sulfide deposits globally.

2) The parental magma was an evolved PGEdepleted low-Mg basaltic magma, which was generated and fractionated in a sub-chamber prior to its emplacement to a shallow crustal level.

3) The genesis of the ore deposit and its Co enrichment (abnormally low Ni/Co compared to 'classic' $\mathrm{Ni}-\mathrm{Cu}$ deposits) are not fully understood, but the following suggestions can be made: i) the magma underwent $\mathrm{Ni}$-depletion via removal of olivine, ii) the presence of hybrid rocks supports a high degree of interaction with mafic magma and country rock, iii) assimilation of country rock ( \pm sulfur \pm metals) decreased the $\mathrm{S}$ solubility and possibly added metals, such as 
$\mathrm{Co}, \mathrm{Cu}, \mathrm{Zn}, \mathrm{Mo}$, and $\mathrm{Pb}$ to the magma, iv) postmagmatic hydrothermal fluids re-precipitated several elements, such as Co, $\mathrm{Zn}$, Mo, and $\mathrm{Pb}$, but v) a very good correlation between $\mathrm{Ni}$ and Co indicates a magmatic control for the distribution of these metals.

4) Sulfur isotope analyses of sulfides (pyrrhotite, chalcopyrite and pyrite) yielded close to mantlelike $S$ isotope compositions, with $\delta^{34} S$ varying from -2.0 to $+4.5 \%$. This can be taken as a weak contamination signal or alternatively and more likely, a so far unrecognized contaminant had a $\delta^{34} S$ value that did not deviate much from the mantle composition.

5) Extensively occurring Paleoproterozoic mafic to ultramafic intrusions associated with S-bearing

\section{References}

Alapieti, T., Filén, B., Lahtinen, J., Lavrov, M., Smolkin, V. \& Voitsekhovsky, S., 1990. Early Proterozoic layered intrusions in the northeastern part of the Fennoscandian Shield. Mineralogy and Petrology 42, 1-22. https://doi.org/10.1007/bf01162681

Arndt, N.T., 1977. Partitioning of nickel between olivine and ultrabasic and basic komatiite liquids. Carnegie Institution of Washington, Yearbook 76, 553-557.

Arndt, N.T., Lesher, C.M. \& Czamanske, G.K., 2005. Mantlederived magmas and magmatic Ni-Cu-(PGE) deposits. In: Hedenquist, J.W., Thompson, J.F.H., Goldfarb, R.J. \& Richards, J.P. (eds.), Economic Geology $100^{\text {th }}$ Anniversary Volume, pp. 5-23.

Barnes, S.-J. \& Lightfoot, P.C., 2005. Formation of magmatic nickel-sulfide ore deposits and processes affecting their copper and platinum-group element contents. In: Hedenquist, J.W., Thompson, J.F.H., Goldfarb, R.J. \& Richards, J.P. (eds.), Economic Geology $100^{\text {th }}$ Anniversary Volume, pp. 179-213.

Barnes, S.-J., Melezhik, V. \& Sokolov, V., 2001. The composition and mode of formation of the Pechenga nickel deposits, Kola Peninsula, Northwestern Russia. Canadian Mineralogist 39, 447-471. https://doi.org/10.2113/gscanmin.39.2.447

Bédard, J.H., 2005. Partitioning coefficients between olivine and silicate melts. Lithos 83, 394-419. https://doi.org/10.1016/j.lithos.2005.03.011

Bekker, A., Barley, M.E., Fiorentini, M.L., Rouxel, O.J., Rumble, D. \& Beresford, S.W., 2009. Atmospheric sulfur country rocks are potential exploration targets to different kinds of mineralization in the Finnish Lapland, including Hietakero-type Co-Cu-Ni deposits.

\section{Acknowledgements}

This study was supported by the Geological Survey of Finland (GTK). We thank Viena Arvola and Pertti Telkkälä for preparing some of the figures. Bo Johanson, Lassi Pakkanen, and Sari Lukkari are thanked for mineralogical studies at the research laboratory of the GTK. Eero Hanski acknowledges the support from the Academy of Finland (grant \#281859). We are grateful to Tapani Rämö and one anonymous reviewer for their valuable comments on the manuscript.

in Archean komatiite-hosted nickel deposits. Science 326, 1086-1089.

https://doi.org/10.1126/science.1177742

Bergman, S., Kübler, L. \& Martinsson, O., 2001. Description of regional geological and geophysical maps of northern Norrbotten county (east of the Caledonian orogeny). Geological Survey of Sweden, Ba 56, 110 p.

Borodaev, Y.S., Bryzgalov, I.A., Mozgova, N.N. \& Uspenskaya, T.Y., 2007. Pentlandite and co-enriched pentlandite as characteristic minerals of modern hydrothermal sulphide mounds hosted by serpentinized ultramafic rocks (MidAtlantic Ridge). Moscow University Geology Bulletin 62, 85-97. https://doi.org/10.3103/s0145875207020032

Brickwood, J.D., 1986. The geology and mineralogy of some $\mathrm{Fe}-\mathrm{Cu}-\mathrm{Ni}$ sulphide deposits in the Bable area, Norway. Norsk Geologist Tiddskrift 66, 189-208.

Brownscombe, W., Ihlenfeld, C., Coppard, J., Hartshorne, C., Klatt, S., Siikaluoma, J.K., \& Herrington, R.J. 2015. The Sakatti Cu-Ni-PGE sulfide deposit in northern Finland. In: Maier, W.D., Lahtinen, R., O’Brien, H. (eds.), Mineral Deposits of Finland. Elsevier, Amsterdam, pp. 211-252.

https://doi.org/10.1016/B978-0-12-410438-9.00009-1

Campbell, I.H. \& Barnes, S.J., 1984. A model for the geochemistry of the platinum group elements in magmatic sulfide deposits. Canadian Mineralogist 22, 151-160.

Czamanske, G.K., Kunilov V.E., Zientek M.L., Cabri L.J., Likhachev A.P., Calk, L.C. \& Oscarson, R., 1992. 
A proton-microprobe study of magmatic sulphide ores from the Noril'sk-Talnakh district, Siberia. Canadian Mineralogist 30, 249-287.

DigiKP - Bedrock of Finland. Digital map database [Electronic resource] Espoo: Geological Survey of Finland [referred 15.2.2017]. Version 1.0. Available at: http://www.geo.fi/en/bedrock.html

Dwarzski, R.E. \& Herd, C.D.K., 2003. Cobalt and nickel partitioning into planetary olivine. Lunar and Planetary Science XXXIV, abstract 1625.

Engvik, A., K., Mezger, K., Wortelkamp, S., Bast, R., Corfu, F., Korneliussen, A., Ihlen, P., Bingen, B. \& Austrheim, H., 2011. Metasomatism of gabbro - mineral replacement and element mobilization during the Sveconorwegian metamorphic event. Journal of Metamorphic Geology 29, 399-423. https://doi.org/10.1111/j.1525-1314.2010.00922.x

Frietsch, R., Tuisku, P., Martinsson, O. \& Perdahl, J.-A., 1997. Early Proterozoic $\mathrm{Cu}-(\mathrm{Au})$ and $\mathrm{Fe}$ ore deposits associated with regional $\mathrm{Na}-\mathrm{Cl}$ metasomatism in northern Fennoscandia. Ore Geology Reviews 12, 1-34. https://doi.org/10.1016/S0169-1368(96)00013-3

Gaetani, G.A. \& Grove, T.L., 1997. Partitioning of moderately siderophile elements among olivine, silicate melt, and sulfide melt: Constraints on core formation in the Earth and Mars. Geochimica et Cosmochimica Acta 61, 18291846. https://doi.org/10.1016/S0016-7037(97)00033-1

Garuti, G., Fiandri, P. \& Rossi, A., 1986. Sulfide composition and phase relations in the $\mathrm{Fe}-\mathrm{Ni}-\mathrm{Cu}$ ore deposits of the Ivrea-Varbano basic complex (western Alps, Italy). Mineralium Deposita 22, 22-34.

https://doi.org/10.1007/bf00204358

Gilbert, S.E., Danyushevsky, L.V., Rodermann, T., Shimizu, A., Gurenko, A., Meffre, S., Thomas, H., Large, R.R. \& Death, D., 2014. Optimisation of laser parameters for the analysis of sulphur isotopes in sulphide minerals by laser ablation ICP-MS. Journal of Analytical Atomic Spectrometry 29, 1042-1051. https://doi.org/10.1039/c4ja00011k

Haapala, I. \& Papunen, H., 2015. A History of exploration for and discovery of Finland's ore deposits. In: Maier, W.D., Lahtinen, R., O’Brien, H. (eds.), Mineral Deposits of Finland. Elsevier, Amsterdam, pp. 1-38. https://doi.org/10.1016/B978-0-12-410438-9.00001-7

Iljina, M. \& Hanski, E., 2005. Layered mafic intrusions of the Tornio-Näränkävaara belt. In: M. Lehtinen, P. Nurmi, T. Rämö (eds.), Precambrian Bedrock of Finland - Key to the Evolution of the Fennoscandian Shield. Elsevier, Amsterdam, pp. 103-138.

https://doi.org/10.1016/S0166-2635(05)80004-0

Iljina, M., Maier, W.D. \& Karinen T., 2015. PGE-(Cu-Ni) deposits of the Tornio-Näränkävaara belt of intrusions (Portimo, Penikat, and Koillismaa). In: Maier, W., Lahtinen, R. \& O’Brien, H. (eds.), Mineral Deposits of
Finland. Elsevier, Amsterdam, pp. 133-164. https://doi.org/10.1016/B978-0-12-410438-9.00005-4

Isohanni, M., Ohenoja, V. \& Papunen, H., 1985. Geology and nickel-copper ores of the Nivala area. In: Papunen, H. \& Gorbunov, G.I. (eds.), Nickel-Copper Deposits of the Baltic Shield and Scandinavian Caledonides. Geological Survey of Finland Bulletin 333, 211-228.

https://doi.org/10.2113/gsecongeo.81.5.1236

Karinen, T., Lepistö, S., Konnunaho, J., Lauri, L.S., Manninen, T. \& Huhma, H., 2015a. Yksikkökuvausraportti Enontekiö, Käsivarsi. Geological Survey of Finland, Archive Report 66/2015, 38 p.

Karinen, T., Lahti, I. \& Konnunaho, J., 2015b. 3D/4D geological modelling of the Hietakero and Vähäkurkkio areas in the Lätäseno Schist Belt, Enontekiö, Northern Finland. In: Sarala, P. (ed.), Novel Technologies for Greenfield Exploration. Geological Survey of Finland, Special Paper 57, 121-134.

Keays, R.R. \& Lightfoot, P.C., 2010. Crustal sulfur in required to form magmatic $\mathrm{Ni}$-Cu sulfide deposits; evidence from chalcophile element signatures of Siberian and Deccan Trap basalt. Mineralium Deposita 45, 241-257. https://doi.org/10.1007/s00126-009-0271-1

Kiseeva, E.S. \& Wood, B.J., 2013. A simple model for chalcophile element partitioning between sulphide and silicate liquids with geochemical applications. Earth and Planetary Science Letters 383, 68-81. https://doi.org/10.1016/j.epsl.2013.09.034

Kiseeva, E.S. \& Wood, B.J., 2015. The effects of composition and temperature on chalcophile and lithophile element partitioning into magmatic sulphides. Earth and Planetary Science Letters 424, 280-294.

https://doi.org/10.1016/j.epsl.2015.05.012

Kitakaze, A. \& Sugaki, A., 2004. The phase relations between $\mathrm{Fe}_{4.5} \mathrm{Ni}_{4.5} \mathrm{~S}_{8}$ and $\mathrm{Co}_{9} \mathrm{~S}_{8}$ in the system Fe-Ni-Co-S at temperatures from $400^{\circ}$ to $1100^{\circ} \mathrm{C}$. Canadian Mineralogist 42, 17-42.

https://doi.org/10.2113/gscanmin.42.1.17

Konnunaho, J., Hanski, E.H., Bekker, A., Halkoaho, T.A.A., Hiebert, R.S. \& Wing, B.A., 2013. The Archean komatiite-hosted, PGE-bearing $\mathrm{Ni}-\mathrm{Cu}$ sulfide deposit at Vaara, eastern Finland: evidence for assimilation of external sulfur and post-depositional desulfurization. Mineralium Deposita 48, 967-989.

https://doi.org/10.1007/s00126-013-0469-0

Konnunaho, J. P., Halkoaho, T.A.A., Hanski, E. J. \& Törmänen, T., 2015. Komatiite-hosted Ni-Cu-PGE deposits of the Finland. In: Maier, W., Lahtinen, R. \& O’Brian, H. (eds.), Mineral Deposits of Finland. Elsevier, Amsterdam, 93-128.

https://doi.org/10.1016/B978-0-12-410438-9.00004-2

Kontinen, A. \& Hanski, E., 2015. The Talvivaara black shalehosted $\mathrm{Ni}-\mathrm{Zn}-\mathrm{Cu}-\mathrm{Co}$ deposit in eastern Finland. In: Maier, W.D., Lahtinen, R. \& O’Brien, H. (eds.), Mineral Deposits of Finland. Elsevier, Amsterdam, pp. 557-612. https://doi.org/10.1016/B978-0-12-410438-9.00022-4 
Kouvo, O., Huhma, M. \& Vuorelainen, Y., 1959. A natural cobalt analogue of pentlandite. American Mineralogist 44, 897-900.

Lamberg, P., 2005. From genetic concepts to practice - Lithogeochemical identification of $\mathrm{Ni}-\mathrm{Cu}$ mineralised intrusions and localisation of the ore. Geological Survey of Finland, Bulletin 402, 264 p.

Lesher, C.M. \& Barnes, S.J., 2009. Komatiite-associated NiCu-(PGE) deposits. In: Chusi, L. \& Ripley, E.M. (eds.), New Developments in Magmatic Ni-Cu and PGE Deposits. Geological Publishing House, Beijing, pp. 27121. https://doi.org/10.1017/cbo9780511535550.011

Lesher C.M. \& Groves D.I., 1986. Controls on the formation of komatiite-associated nickel-copper sulfide deposits. In: Friedrich, G., Genkin, A. D. et al. (eds.), Geology and Metallogeny of Copper Deposits. Springer, Berlin, pp. 151-170. https://doi.org/10.1007/978-3-642-70902-9_4

Li, C.M. \& Ripley, E.M., 2005. Empirical equations to predict the sulfur content of mafic magmas at sulfide saturation and applications to magmatic sulfide deposits. Mineralium Deposita 40, 1173-1180. https://doi.org/10.1007/s00126-005-0478-8

Li, C., Maier, W.D. \& de Waal, S.A., 2001. Magmatic Ni-Cu versus PGE deposits: Constraining genetic controls and exploration implications. South African Journal of Geology 104, 309-318.

https://doi.org/10.2113/104.4.309

Li, Y., 2014. Chalcophile element partitioning between sulfide phases and hydrous mantle melt: Applications to mantle melting and the formation of ore deposits. Journal of Asian Earth Sciences 94, 77-93.

https://doi.org/10.1016/j.jseaes.2014.08.009

Liu, Y., Samaha, N.T. \& Baker, D.R., 2007. Sulfur concentration at sulfide saturation (SCSS) in magmatic silicate melts. Geochemica et Cosmochimica Acta 71, 1783-1799.

https://doi.org/10.1016/j.gca.2007.01.004

MacLean, W.H., 1969. Liquidus phase relations in the FeS$\mathrm{FeO}-\mathrm{Fe}_{2} \mathrm{O}_{3}-\mathrm{SiO}_{2}$ system and their application in geology. Economic Geology 64, 865-884. https://doi.org/10.2113/gsecongeo.64.8.865

Maier, W.D. \& Barnes, S.-J., 2010. The Kabanga Ni sulfide deposits, Tanzania: II. Chalcophile and siderophile element geochemistry. Mineralium Deposita 45, 443460. https://doi.org/10.1007/s00126-010-0283-x

Makkonen, H.V., 2015. Nickel deposits of the $1.88 \mathrm{Ga}$ Kotalahti and Vammala belt. In: Maier, W.D., Lahtinen, R. \& O’Brien, H. (eds.), Mineral Deposits of Finland. Elsevier, Amsterdam, pp. 253-290. https://doi.org/10.1016/b978-0-12-410438-9.00010-8

Makkonen, H.V., Halkoaho, T., Konnunaho, J., Rasilainen, K. \& Eilu, P., 2017. Ni-(Cu-PGE) deposits in Finland
- Geology and exploration potential. Ore Geology Reviews 90, 667-696.

https://doi.org/10.1016/j.oregeorev.2017.06.008

Menard, T., Lesher, C.M., Stowell, H.H., Price, D.P., Pickell, J.R., Onstott, T.C. \& Hulbert, L., 1996. Geology, genesis, and metamorphic history of the Namew Lake $\mathrm{Ni}-\mathrm{Cu}$ deposit, Manitoba. Economic Geology 91, 1394-1413. https://doi.org/10.2113/gsecongeo.91.8.1394

Merkle, R.K.W. \& von Gruenewaldt, G., 1986. Compositional variation of Co-rich pentlandite; relation to the evolution of the upper zone of the western Bushveld Complex, South Africa. Canadian Mineralogist 24, 529-546.

Miller, D.J. \& Cervantes, P., 2002. Sulfide mineral chemistry and petrography and platinum group element composition in gabbroic rocks in the Souhtwest India Ridge. In: Natland, J.H., Dicks, H.J.B, Miller, D.J \& von Hertzen, R.P. (eds.), Proceedings of Ocean Drilling Program, Scientific Results, Volume 176, 1-29. https://doi.org/10.2973/odp.proc.sr.176.009.2002

Müller, W., Shelley, M., Miller, P. \& Broude, S., 2009. Initial performance metrics of a new custom-designed $\mathrm{ArF}$ excimer LA-ICPMS system coupled to a two-volume laser-ablation cell. Journal of Analytical Atomic Spectrometry 24, 209-214.

https://doi.org/10.1039/b805995k

Mutanen, T., 1997. Geology and ore petrology of the Akanvaara and Koitelainen mafic layered intrusions and the Keivitsa-Satovaara layered complex, northern Finland. Geological Survey of Finland, Bulletin 395, 233 p.

Naldrett, A.J., 1989. Magmatic Sulfide Deposits. Oxford University Press, Oxford, New York, 186 p.

Naldrett, A.J., 2004. Magmatic Sulfide Deposits: Geology, Geochemistry and Exploration. Springer-Verlag, Berlin, $724 \mathrm{p}$. https://doi.org/10.1007/978-3-662-08444-1

Nironen, M. (ed.), 2017. Bedrock of Finland at the scale 1:1000 000 - Major stratigraphic units, metamorphism and tectonic evolution. Geological Survey of Finland, Special Paper 60,77 p.

Pankka, H.S. \& Vanhanen, E.J., 1992. Early Proterozoic $\mathrm{Au}-\mathrm{Co}-\mathrm{U}$ mineralization in the Kuusamo district, northeastern Finland. Precambrian Research 58, 387-400. https://doi.org/10.1016/0301-9268(92)90126-9

Papunen, H. \& Koskinen, J., 1985. Geology of the Kotalahti nickel-copper ore. In: Papunen, H. and Gorbunov, G.I. (eds.), Nickel-Copper Deposits of the Baltic Shield and Scandinavian Caledonides. Geological Survey of Finland, Bulletin 333, 228-240.

Park, Y.-R., Ripley, E.M., Miller, J.D., Li, C., Mariga, J. \& Shafer, P., 2004. Stable isotopic constraints on fluid-rock interaction and Cu-PGE-S redistribution in the Sonju Lake intrusion, Minnesota. Economic Geology 99, 325338.

https://doi.org/10.2113/gsecongeo.99.2.325 
Peltonen, P., 1995. Magma-country rock interaction and the genesis of $\mathrm{Ni}-\mathrm{Cu}$ deposits in the Vammala Nickel Belt, SW Finland. Mineralogy and Petrology 52, 1-24. https://doi.org/10.1007/bf01163124

Peltonen, P., Kontinen, A., Huhma, H. \& Kuronen, U., 2008. Outokumpu revisited: new mineral deposit model for the mantle peridotite-associated $\mathrm{Cu}-\mathrm{Co}-\mathrm{Zn}-\mathrm{Ni}-\mathrm{Ag}-\mathrm{Au}$ sulphide deposits. Ore Geology Reviews 33, 559-617. https://doi.org/10.1016/j.oregeorev.2007.07.002

Pinto, V.M., Hartmann, L.A., Wildner, W., Porcher, C.C. \& Chemale, Jr., F., 2015. Occurrence of pyrrhotite, copentlandite and chalcopyrite in the high- $\mathrm{Mg}$ rocks of the Morungava intrusion, Paraná Igneous Province, southernmost Brazil. Annals of IX Simpósio Sul Brasileiro de Geologia, Florianópolis, Brasil, April 28th May $1^{\text {st }}, 2015$, Abstracts.

Ripley, E.M. \& Li, C., 2003. Sulfur isotope exchange and metal enrichment in the formation of magmatic $\mathrm{Cu}-\mathrm{Ni}$-(PGE) deposits. Economic Geology 98, 635-641. https://doi.org/10.2113/gsecongeo.98.3.635

Ripley, E.M. \& Li, C., 2013. Sulfide saturation in mafic magmas: Is external sulfur required for magmatic $\mathrm{Ni}-\mathrm{Cu}-$ (PGE) ore deposits. Economic Geology 108, 45-58. https://doi.org/10.2113/econgeo.108.1.45

Ripley, E.M., Li, C. \& Shin, D., 2002. Paragneiss assimilation in the genesis of magmatic $\mathrm{Ni}-\mathrm{Cu}-\mathrm{Co}$ sulfide mineralization at Voisey's Bay, Labrador $-\delta^{34} \mathrm{~S}, \delta^{13} \mathrm{C}$, and Se/S evidence. Economic Geology 97, 1307-1318. https://doi.org/10.2113/gsecongeo.97.6.1307

Santaguida, F., Luolavirta, K., Lappalainen, M., Ylinen, J., Voipio, T. \& Jones, S., 2015. The Kevitsa Ni-Cu-PGE deposit in the Central Lapland greenstone belt in Finland. In: Maier, W., Lahtinen, R. \& O’Brien, H. (eds.), Mineral Deposits of Finland, Elsevier, Amsterdam, pp. 195-210. https://doi.org/10.1016/B978-0-12-410438-9.00008-X

Seat, Z., Stone, W.E., Mapleson, D.B. \& Daddow, B.C., 2004. Tenor variation within komatiite-associated sulphide deposits: insights from the Wannaway Deposit, Widgiemooltha Dome, Western Australia. Mineralogy and Petrology 82, 317-339.

https://doi.org/10.1007/s00710-004-0047-3
Seat, Z., Beresford, S.W., Grguric, B.A., Gee, M.A.M. \& Grassineau, N.V., 2009. Reevaluation of the role of external sulphur addition in the genesis of $\mathrm{Ni}-\mathrm{Cu}-\mathrm{PGE}$ deposits - Evidence from the Nebo-Babel Ni-Cu-PGE deposit, West Musgrave, Western Australia. Economic Geology 104, 521-538. https://doi.org/10.2113/gsecongeo.104.4.521

Tang, Z., Song, X-Y. \& Su, S. 2009. Ni-Cu deposits related to high-Mg basaltic magma, Jinchuan, Western China. In: Li, C. and Ripley, E.M. (eds.), New Developments in Magmatic Ni-Cu and PGE Deposits. Geological Publishing House Beijing, China, pp. 121-141

Teertstra, D.K. \& Sherriff, B.L., 1997. Substitutional mechanism, compositional trends and end-member formulae of scapolite. Chemical Geology 136, 233-260. https://doi.org/10.1016/S0009-2541(96)00146-5

Theriault, R.D. \& Barnes, S.J., 1998. Compositional variations in $\mathrm{Cu}-\mathrm{Ni}$-PGE sulfides of the Dunka Road deposit, Duluth complex, Minnesota: the importance of combined assimilation and magmatic processes. Canadian Mineralogist 36, 869-886.

Tisserant, A \& Pauliuk, S., 2016. Matching global cobalt demand under different scenarios for co-production and mining attractiveness. Journal of Economic Structures 5 . https://doi.org/10.1186/s40008-016-0035-x

Tomkins, A.G., Rebryna, K.C., Weinberg, R.F. \& Schaefer, B.F., 2012. Magmatic sulfide formation by reduction of oxidized arc basalt. Journal of Petrology 53, 1537-1567. https://doi.org/10.1093/petrology/egs025

Törmänen, T., Konnunaho, J.P., Hanski, E., Moilanen, M. \& Heikura, P., 2016. The Paleoproterozoic komatiitehosted PGE mineralization at Lomalampi, Central Lapland Greenstone Belt, northern Finland. Mineralium Deposita 51, 411-430. https://doi.org/10.1007/s00126-015-0615-y

Vasilopoulos, M. 2015. Geochemical, mineralogical and fluid inclusion study of the Juomasuo Au-Co deposit, Kuusamo schist belt, north-eastern Finland: Implications for alteration control on mineralization. Master's thesis, Oulu Mining School, University of Oulu, $114 \mathrm{p}$.

Vuorisjärvi, E. 1990. Petsamon nikkeli kansainvälisessä politiikassa 1939-1944. Otava, Keuruu, 267 p. 